\title{
Hydrogeology of the
}

Upper Capibaribe Basin

Pernambuco, Brazil-

$m$

A Reconnaissance in an

Area of Crystalline Rocks

GEOLOGICAL SURVEY WATER-SUPPLY PAPER 1663-E

Prepared in cooperation with the Superintendência do Desenvolvimento do Nordeste of Brazil under the auspices of the U.S. Agency for International Development

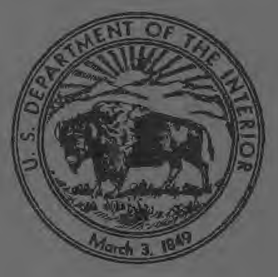




\section{Hydrogeology of the}

\section{Upper Capibaribe Basin}

\section{Pernambuco, Brazil-}

\section{A Reconnaissance in an}

\section{Area of Crystalline Rocks}

By LUIZ GONÇALVES CHADA FILHO, MÁRIO DIAS PESSOA, and WILLIAM C. SINCLAIR

CONTRIBUTIONS TO THE HYDROLOGY OF LATIN AMERICA AND THE ANTILLES

GEOLOGICAL SURVEY WATER-S UPPLY PAPEP, 1663-E

Prepared in cooperation with the Superintendencia do Desenvolvimento do Nordeste of Brazil under the auspices of the U.S. Agency for International Development

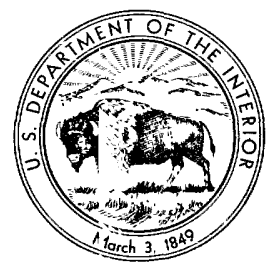




\section{UNITED STATES DEPARTMENT OF THE INTERIOR}

WALTER J. HICKEL, Secretary

\section{GEOLOGIGAL SURVEY}

William T. Pecora, Director 


\section{CONTENTS}

\begin{tabular}{|c|c|}
\hline \multirow{2}{*}{\multicolumn{2}{|c|}{ Abstract }} \\
\hline & \\
\hline & \\
\hline Purpose and scope & \\
\hline d extent of area. & \\
\hline tions_- & \\
\hline stigation & \\
\hline dgments & \\
\hline hy & \\
\hline Topography & \\
\hline Drainage & \\
\hline 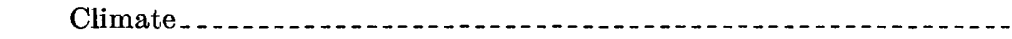 & \\
\hline Population & \\
\hline on & \\
\hline lopment_. & \\
\hline pper Capibaribe basin & \\
\hline 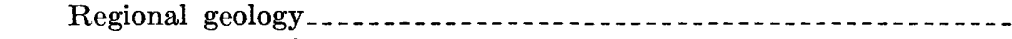 & 12 \\
\hline 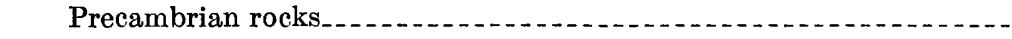 & 14 \\
\hline ology & 16 \\
\hline - & 19 \\
\hline 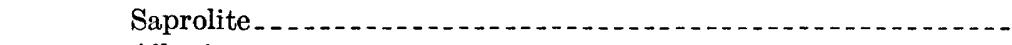 & \\
\hline 㐌 & \\
\hline $\begin{array}{l}{ }^{\prime} \\
\end{array}$ & 0 \\
\hline 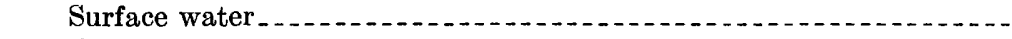 & 22 \\
\hline 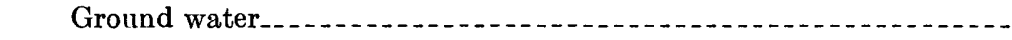 & 25 \\
\hline recambrian crystalline rocks & 25 \\
\hline rilling operations in Precambrian rocks & 26 \\
\hline e'n- & \\
\hline 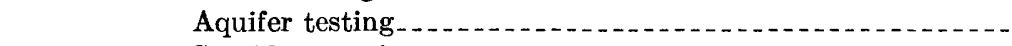 & \\
\hline ty & \\
\hline 县 & 31 \\
\hline 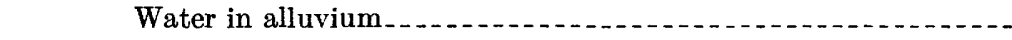 & 31 \\
\hline ter & $3:$ \\
\hline nan consumption & 3 \\
\hline 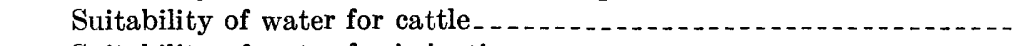 & \\
\hline tion & 36 \\
\hline r resources & 37 \\
\hline of water resources & 38 \\
\hline lusions & 39 \\
\hline - - - & 4 \\
\hline & \\
\hline
\end{tabular}




\section{ILLUSTRATIONS}

Prate 1. Hydrogeologic maps of the Capibaribe basin, Pernambuco, Brazil........ In pocket

Frgure 1. Map showing locations of wells at Jataúba $\ldots \ldots \ldots \ldots$ E21

2. Graphs of daily streamflow at Toritama and Limoeiro in 1964_- 23

3. Graph of semilogarithmic curve showing recovery of water level

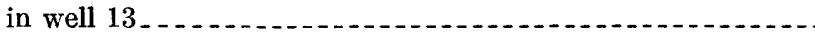

\section{TABLES}

TABLE 1. Geological formations of northeast Brazil according to Ebert_-

2. Flow in Rio Capibaribe and five tributaries on selested dates in 1964

3. Estimated precipitation, runoff, and storage and evaporation, 1964

(19)

4. Records of wells and springs in the upper Capibaribe basin, Pernambuco.

5. Cities and towns in the upper Capibaribe basin and their water supplies

6. Chemical analyses of water from wells, springs, and streams in the upper Capibaribe basin, Perambuco 


\title{
HYDROGEOLOGY OF THE UPPER CAPIBARIBE BASIN PERNAMBUCO, BRAZIL - A RECONNAISSANCE IN AN AREA OF GRYSTALLINE ROGKS
}

\author{
By Luiz Gongalves Chada Filho, ${ }^{1}$ Mário Dias Pessoa ${ }^{1}$ and William C. \\ SINCLAIR ${ }^{2}$

\section{ABSTRACT}

The upper Capibaribe basin is the western three-fourths, approximately, of the valley of the river that empties into the Atlantic Ocean at Recife, the capital of the State of Pernambuco, Brazil. It is the part of the drainage basin that is within the Drought Polygon of northeast Brazil, and it totals about 5,400 square kilorneters. It receives relatively abundant precipitation in terms of the annual average, yet is regarded as hot subhumid to semiarid because the precipitation is uneven from year to year and place to place. The dependable water supply, therefore, is small.

The basin has water, which could be put to better use than at present, but the opportunities for augmenting the usable supply are not great. The stresms are intermittent and therefore cannot be expected to fill surface reservoirs and to keep them filled. The ground-water reservoirs have small capacity-quickly filled and quickly drained.

A rough estimate based on the records for 1964 suggests that, of 4.700 million cubic meters of precipitation in the upper Capibaribe basin, 2.700 millicn cubic meters ( 57 percent) left the basin as runoff and 2,000 million cubic meters ( 43 percent) went into underground storage or was evaporated or transpired.

The bedrock of the upper Capibaribe basin is composed of granite, gneiss, schist, and other varieties of crystalline rocks, which have only insignificant primary permeability. They are permeable mainly where fractured. The principal fracture zones, fortunately, are in the valleys, where water accumulates and can feed iuto them, but the volume of fractured rock is small in relation to the lasin as a whole. A well in a large water-filled fracture zone may yield up to 20,000 liters per hour, but the average well yields less than one-fourth this amount, and some wells yield none.

The saprolite, or weathered rock, is many meters thick at some places especially in the eastern half of the upper Capibaribe basin. It contains water locally, but ordinarily will yield only small quantities to wells.

\footnotetext{
${ }^{1}$ Geologist, Superintendência do Desenvolvimento do Nordeste.

2 Geologist, U.S. Geological Survey.
} 
The alluvium probably is the most productive aquifer in the basin, but is limited to narrow bands along the rivers that generally are no more than a few hundred meters wide and 5 meters thick. The alluvium contains rariable amounts of silty sand capable of yielding small to moderate quantities $o^{f}$. water to wells. Wells driven or dug into the alluvium could solve many small water problems.

The chemical quality of the water in the upper Capibaribe besin ranges from good to bad and generally presents a major problem that cannot be solved solely by applying geological criteria. Mineralized water is $w^{\prime}$ despread in the area, both in streams and underground, and the choice of aquifers is small. All known aquifers contain, at one place or another, water that is mineralized, leaving no alternative for a natural supply of good-quality water. Although much of the available water is unsatisfactory for human consumption, it is generally acceptable for animals and therefore meets one of the principal water needs. Some of the ground water could be made potable by diluting it with rainwater, which could be collected during rainy seasons and temporarily stored in cisterns or reservoirs.

\section{INTRODUCTION}

This report describes the geology and hydrology of the upper Capibaribe basin in the Estado de (State of) Pernambuco. It offers a preliminary analysis of the factors that control the hydrologic system of the basin and especially the factors that affect the arailability and usability of ground water. Thus it deals with the topogrephy, geology, climate, and drainage system of the area and with the chemical characteristics of the water.

The economy of the upper Capibaribe basin has been agricultural since the first settlers arrived. Cattle and, to a lesser degree, cotton have largely dominated the agricultural and commercial activities in the basin. The major towns, among them Limoeiro, Brejo da Madre de Deus, Santa Cruz ro Capibaribe, and Taquaritinga do Norte, which were established about the middle of the 18th century, still serve principally as trading centers for the areas surrounding them and as shipping centers for local agricultural products destined for markets elsewhere.

The economic development of the basin throughout its occupancy has often been restricted by the unreliability of its water supply. This unreliability manifests itself in the capricious irregularity of the precipitation and in the seemingly erratic occurrence of ground water. The precipitation ranges from excessive in wet years to seric isly deficient in dry ones, and much of it runs off or evaporates becaus? the rocks at many places have little capacity to absorb or store water. Accordingly, agricultural enterprises must be governed by these facts, or fail.

The availability of water is a principal factor controlling the distribution of population in the basin. The western (upner) part receives considerably less precipitation, on the average, then the eastern (lower) part. The western part is generally semiarid, and in it the the farms and settlements generally are close to streams. On the other 
hand in the eastern part, where the precipitation is more al undant, the small settlements and farms are dispersed through the countryside. In this part, shallow wells dug in the saprolite, or in the alluvial sediments along even small streams, are adequate sources cf water through the normal dry season, which may last several montl a. They are inadequate, however, in droughts lasting 2,3 , or more years, which occasionally sear the region.

Many attempts have been made to control the erratic wate: supply of the basin. Individual landowners early tried constructing small dams and reservoirs. Later, the Departamento Nacional de Obras Contra as Sêcas (DNOCS, National Department for Drought Reliof) constructed larger dams. The surface reservoirs, however, have not proved wholly successful. Evaporation takes large quantities of water from them and thereby increases the salinity of the remaining water. In some reservoirs the water has become a brine, which not on'y is unusable but may, on escaping from the reservoir, contaminate surface water or ground water downstream from the dam.

Wells have not been notably successful either, although various attempts to construct them have been made by the DNOCS, by the Departamento Estadual de Poços e Açudagem of the State of Pernambuco (Pernambuco State Department of Wells and Dams), and by individuals. Even some wells drilled at sites selected in accord with geological criteria have failed because (1) the rocks proved to be less fractured than anticipated, (2) the fractures had been saaled by the deposition of mineral matter in them, or (3) the water was exceptionally mineralized.

\section{PURPOSE AND SCOPE}

The quantity and quality of water in any area limit the type and degree of economic development that can be carried out in the area. This is true whether the water supply is principally from st:eams or ground water. Its quantity and quality also govern, to a conriderable degree, the type of development for making use of the water. For example, a ground-water supply, no matter how ample it may be, will not be developed by means of wells for irrigation if the water is so saline that it will ruin the soil. The limitations imposed by the quantity and quality of water are therefore outlined in this report so that the development of the water, and of the basin as an economic unit, may be orderly and efficient.

The scope of this report is preliminary because the present utilization of water in the basin is not great and is not likely to increase rapidly or soon. Water is needed mainly for domestic use in small towns and villages and for cattle, and the report is especially oriented to these needs. 


\section{LOCATION AND EXTENT OF AREA}

The Rio Capibaribe originates in northern Pernambuco, about 200 $\mathrm{km}$ (kilometers) west of the Atlantic coast, and empties into the ocean at Recife, the State capital (pl. 1). The basin is oval in outline, becoming narrower as it approaches the Atlantic coast; is gnnerally less than $50 \mathrm{~km}$ wide; and totals about $74,000 \mathrm{sq} \mathrm{km}$ (square kilometers) in area. The part of the basin considered in this report is that within the Drought Polygon, amounting to about 5,400 sq km. The eastern limit of the Drought Polygon cuts northeastward across the basin near the city of Limoeiro (long. $35^{\circ} 22^{\prime} 30^{\prime \prime}$ ), which is about, $75 \mathrm{~km}$ from the coast.

\section{PREVIOUS INVESTIGATIONS}

Although the DNOCS had built several dams and drilled several water wells in the basin, no previous attempt seems to have been made to analyze and describe the hydrologic system of the basin. The basin is included, of course, on the geologic maps of Pernambuco published by Moraes (1928) and Dias (1957), but these maps are not sufficiently detailed for hydrologic studies. A report by Mangualde. (1945) includes part of the basin but provides geologic data only for localities having mineral deposits. The stratigraphy and structural geology of an area that includes the western half of the basin were described by Ebert (1962) in a paper originally published in German. Translated into Portuguese, this paper has been mimeographed for circulation within the Superintendência do Desenvolvimento do Nordeste (SUDENE, Superintendency for Development of the Northeast) under the title "Tectonica e metamorfismo regional do escudo Brasilerio." The part of the basin west of long. $36^{\circ}$ is included in geologic quadrangle maps, entitled "São João do Cariri" and "Garanhuns," of the reconnaissance photogeologic series published by the Departamento Nacional de Produção Mineral (National Department of Mineral Production).

Only a few springs occur in the basin, but some are well known and have been described in reports published by the State of Pernambuco (Pinto, 1942a, 1942b, Teixeira, 1945). The springs at Fazenda Nova, Carapotós, and Salgadinho have long been used and are still in use to some extent.

\section{METHODS OF INVESTIGATION}

The methods used in this investigation are methods common to reconnaissance hydrogeologic investigations. The rock exposures were studied in the field, and a geologic map was prepared. The map published with this report is a synthesis of the field observations, the work of Ebert (1955), and the Garanhuns and São João do Cariri photo- 
geologic maps. Even so, it covers only the part of the basin west of long. $36^{\circ}$, because the difficulties in mapping proved to be insurmountable in the time available. Although a reasonably good drainage map was produced for the eastern part, the road network, which wis based on information at least 15 years old, was unreliable. The rcads trarersed in the field could not be identified with certainty with those shown on the map, and the geologists, therefore, could not be sure of geographic positions except near towns. No aerial photographs were available. Lacking time to prepare their own base map by laborious surveying techniques, the geologists, had to content themselves with generalized geological observations in the eastern part of the basin.

Data on wells were obtained by locating and measuring the few existing wells. The springs were examined, and samples of woter were collected from them. These data were supplemented by obserration of the drilling and testing operations in wells caried out by the Departamento Estadual de Poços e Açudagem under a program of well derelopment of the State of Pernambuco, which fortunately was begun shortly after this investigation was started. The geologists assigned to the investigation were invited to paricipate in selecting the well sites and thus were able to take advantage of the information provided by this drilling program.

Streamflow information obtained from the Departamento Nacional de Obras de Saneamento (National Department of Sanitary Works) was restricted to gage-height records of the Rio Capibaribe at Toritama and Limoeiro. This information was supplemented by meas'rements of streamflow made at several locations within the basin, which were repeated one to three times.

Other water samples were collected from existing wells, from wells drilled for the Departamento Estadual de Pocos e Açudagem, and from the streams. These samples were analyzed in the water laboratory of SUDENE. The laboratory analyses were supplemented by field determinations of chloride, hardness, and specific conductance made with field chemical-testing equipment. Altitudes of the land surfaces at wells and springs were determined by altimeter surveys.

The investigation was made under the Aliança para o Progresso. It was a joint project of the Divisão de Hidrogeologia of SUDENE, of which Geraldo de Azevedo Gusmão is chief, and the Natural Pesources Branch, U.S. Agency for International Development. Stuart I. Schoft, of the U.S. Geological Survey, as supervisor in charge of ground-water investigations for the Agency for International Development, gave general guidance to the project.

All three authors participated in all phases of the investigation, but not to the same extent. Luiz Gonçalves Chada Filho and Mário Dias 
Pessoa of SUDENE assumed the principal responsibility for the geologic work, including the geologic mapping and the section of the report dealing with the rocks of Precambrian age. William C. Sinclair of the U.S. Geological Survey assumed principal responsibility for the hydrology.

\section{ACKNOWLEDGMENTS}

The authors of this report are grateful to many residents of the upper Capibaribe basin who provided information or helped in other ways. Special thanks are due to Abelardo Cardoso Montenegro, chief engineer, and Germano Schnaider, engineer, of the Hydraulic Laboratory of the Departamento Nacional de Obras de Saneamento, for records of the stream-gaging stations at Limoeiro and Toritama and to Newton T. Prestrelo, chief of the Divisão de Poços (Well Division) of the Departamento Estadual de Poços e Açudagem, for arranging close coordination with the well-drilling crews under contract to the State.

\section{GEOGRAPHY}

The upper Capibaribe basin is, as its name suggests, part of a single hydrographic unit. It has a rolling, in part rugged, topog:aphy and a hot subhumid to semiarid climate. Its climate is transiticnal between that of the forested coastal belt and the dry interior of northeast Brazil. The basin lies between major routes of communication with the Atlantic coast. It has good communication with commercial centers to the north and south, but plainly this is the secondary direction of commercial movement in the region. The basin, therefore, is relatively isolated from the main stream of commercial movement.

\section{TOPOGRAPHY}

The upper Capibaribe basin forms a part of the Planelto da Borborema, an extensive regional peneplain now undergoing dissection, but the basin, considered by itself, resembles neither a penoplain nor a plateau. Much of it is too rugged. Roughly oval in outline, the basin is bounded by mountainous ridges, which at the upper end rise about $900 \mathrm{~m}$ (meters) above the principal streams and more than $1,000 \mathrm{~m}$ above sea level. Even at the eastern boundary of the area here considered, the limiting ridges are about $150 \mathrm{~m}$ or more above the channel of the Rio Capibaribe and $300 \mathrm{~m}$ above sea level. The maximum relief is nearly $1,000 \mathrm{~m}$.

Although the local relief generally amounts to less than $1.00 \mathrm{~m}$, many tributary valleys, especially in the mestern part (west of Toritama), are youthful. They are deep and narrow, and their longitudinal profiles are steep and irrgular. The ridges are steep and expose much 
barren bedrock. Large loose blocks of rock and partly rounded boulders are abundantly scattered about, even on slopes that are relatively gentle.

The part of the basin east of Toritama, on the other hand, is less rugged, although the local relief generally amounts to many meters. The hills are more smoothly rounded, the soils thicker, and the rock exposures fewer. Loose rocks and boulders are scarce. The difference is due to deeper weathering of the bedrock, partly because precipitation is heavier than it is farther west and partly because easily erodible schist is the dominant bedrock.

Valley bottoms are narrow; thus even the bottom land of the Rio Capibaribe at Limoeiro, at the downstream boundary of the report area, is only about $100 \mathrm{~m}$ wide. This narrowness points to an obvious limitation in the amount of bottom land available for irrigated agriculture and in the amount of alluvium available along streams for storing ground water. Possibly the largest relatively flat areas are the upland plains in the northeast, on which the towns of Vertentes and Surubim are located. Although dissected by many small streams, these plains are dominant features. The valley bottoms are in an area measuring 35 to $40 \mathrm{~km}$ from east to west.

\section{DRAINAGE}

The drainage system in the upper Capibaribe basin is well developed, but all the streams are ephemeral, including the Capibaribe itself. The main stream heads in the extreme southwestern part of the basin, east of the village of Fundão, which is just outside the basin (pl. 1). The stream flows east-northeast to Santa Cruz do Capibaribe, which is near the middle of the area studied, and thence east, crossing the eastern boundary of the Drought Polygon near Limoeiro.

Among the named tributaries of the Rio Capibaribe entering the main stream from the south side are Riacho Tabocas, which passes near Brejo da Madre de Deus; Riacho Fazenda Velha-Riacho Volta Grande, which passes near Fazenda Nova; and Riacho das Eguas, which passes near the town of Riacho das Almas. Named tributaries entering the main stream from the north side include Riacho do Jatobá, which passes near the town of Jataúba; Riacho Tapera, which empties into the main stream near Santa Cruz do Capibaribe; Riacho Tapada, which passes east of Vertentes; and Rio Caiaí, which empties into the main stream a few kilometers above Salgadinho.

The drainage net and the topography in the upper Capibaribe basin are the result of differential erosion of the bedrock, which exhibits considerable differences in rock type and structure from place to place. Principal tributaries in the southwestern part of the basin have nearly 
parallel northeastward courses following a dominant str"ıtural alinement of the rocks, and they enter the main stream at an acute angle. Many tributaries on the north side, however, enter the main stream nearly at right angles. Tributaries on both sides make abrupt bends, many of which are doubtless controlled by faults or major joints. Thus the drainage net, although not typically trellised, is angular in much of the basin. The drainage net in the eastern part, horever, is dendritic in places, probably because the zone of weathered rock is thick, covering the bedrock and minimizing its influence on the courses of the minor tributaries. The main stream could be described as nearly straight in a west-to-east course if the branch known as Riacho do Jatobá had been named "Capibaribe" instead of the som?what longer south-western branch. However, the river makes two sharp, nearly equal bends. Near Poço Fundo it turns abruptly northeast for $5 \mathrm{~km}$, then takes a course east-southeast for $21 \mathrm{~km}$, and then, nfar Toritama, turns abruptly $4.5 \mathrm{~km}$ south to resume its eastward course on approximately the original alinement. The drainage system, formed along zones of weakness in the rock, provides clues to the locations where fractures may contain water.

\section{CLIMATE}

The climate of the upper Capibaribe basin is characterized as hot and semiarid, with generally unreliable precipitation. It is a climate of the Drought Polygon, but because the area borders the boundary of the Polygon, it is transitional to the climate of the humid littoral zone. The temperatures, when averaged by months, seem not to be excessive, ranging from $20^{\circ} \mathrm{C}$ for July to $24^{\circ} \mathrm{C}$ for December. Daily variations, however, can amount to $15^{\circ} \mathrm{C}$ and can send the lowest daily temperature substantially below $20^{\circ} \mathrm{C}$ and the highest close to $40^{\circ} \mathrm{C}$ (Departmento Nacional de Produçâo Mineral, 1948). Tl a figures are averages for the whole basin. Places in the east or the west, or very high or low, will have temperatures differing considerably from the average.

The precipitation, as judged principally by the vegetation it supports, increases irregularly from west to east. It generally ranges from 300 to $800 \mathrm{~mm}$ (millimeters) per year (Departmento Nacional de Obras Contras as Sêcas, 1958). At Brejo da Madre de Deus, which has the only long-term pluviometric station within the basin, the average annual precipitation is $858 \mathrm{~mm}$, but this may be higher than the true average for the basin because topographic and climatic factors combine to make that locality unusually wet. The western part of the basin has vegetation consisting typically of thom brusl and cactus. On the other hand the part east of Toritama has more trees than brush, and the vegetation is green throughout practically the whole year, verging on lush at the boundary of the Drought Polygon. 
The statistics for annual average rainfall fail to portray the real problems of precipitation in northeast Brazil in general, or in the upper Capibaribe basin in particular. The variations in precipitation tell more. There are wide variations in monthly precipitation, wide variations in annual precipitation, and wide variations betweer places. The annual variations are shown in 25 years of record at nine weather stations in the region of which the upper Capibaribe basin is a part (pl. 1). Of these, the one at Brejo da Madre de Deus is somewhat west of the middle of the area considered in this report; at Monteiro, farthest west; at Cabaceiras, farthest north; at Escada, farthest south; and at Recife, farthest east. Recife, Escada, and Carpina although not in the Drought Polygon, are included on plate 1 in order to show the transition from the arid interior to the humid coast. The average annual precipitation at these nine stations ranges from $279 \mathrm{~mm}$ (at Cabaceiras) to $1,693 \mathrm{~mm}$ (at Escada).

Monthly variations shown by bar graphs on plate 1 make it clear that the rainy season generally begins in March and lasts 4 to 6 months. The month of heaviest precipitation is March at Brejo da Madre de Deus and Cabaceiras; April at Monteiro and Pesqueira; May at Bom Jardim, Carpina, Escada, and Recife; and June at Cumaru. In general, March, April, and May are the wettest months in the eastern part of the area. The bar graphs show that precipitation diminishes rapidly after the peak has been passed, and that it may be negligible in 25 to 35 percent of the year.

The variations in amount of precipitation from year to year may be as much as 50 percent, and the geographic distribution of the precipitation is often erratic. For example, the wettest 3 years at Bom Jardim were 1949-51, when the precipitation was 50 percent above normal. Yet in the same 3 years, the precipitation at Caruaru, only $70 \mathrm{~km}$ away, a veraged 30 percent below normal.

The topography plays an important part in controlling the distribution of precipitation. If many rain gages could be distributed throughout the upper Capibaribe basin, at a variety of altitudes and in differing topographic situations, they would show variations that are concealed in the records of the sparsely distributed long-term stations. The possible range in such variations is suggested on plate 1 , which shows the total precipitation recorded in 1964 at 14 newly established pluviometric stations in the basin, together with the old one at Brejo da Madre de Deus and others on the periphery of the basin.

High peaks and ridges obstruct the movement of airmasses, which are forced upward to altitudes where decreased atmospheric pressure and lower temperature induce precipitation. Locally, the configuration of valleys and hills concentrates the precipitation, resulting in humid 
areas called "brejos," in the midst of general aridity. The lush vegetation and flourishing agriculture of these areas contrast sharply with their surroundings. Typical examples are Brejo da Madre de Deus and Taquaritinga do Norte.

The potential for evaporation and transpiration is greatest during dry seasons, but the actual evaporation and transpiration often are greatest during wet seasons, because water is available then to be evaporated. The transpiration has not been measured in the upper Capibaribe basin. The potential for evaporation, however, may be as much as $1,000 \mathrm{~mm}$ per year, ranging from $60 \mathrm{~mm}$ per month in the rainy season (winter) to $140 \mathrm{~mm}$ in summer (Departamento Nacional de Produçâo Mineral, 19t8). The western part of the basin, where cloud cover and precipitation are least, has the highest potential for evaporation.

\section{POPULATION}

The population of the upper Capibaribe basin is about 265,000 , of which about 80 percent ( 214,000 persons) is rural. Population density averages about 40 inhabitants per $\mathrm{sq} \mathrm{km}$, but generally ranges from 30 in the arid western part to 100 in the humid eastern part.

Linroeiro, with a population of 21,252 in 1960 , is the largest city in the area and the principal commercial center for the easters part of the area studied. It is $75 \mathrm{~km}$ by pared road northwest of Recife, the State capital and a major seaport. Caruaru, although outside the basin to the south, is an important commercial center serving the western part of the basin. It is about $130 \mathrm{~km}$ west of Recife. Populations of other towns in the basin are given in table 5 .

\section{TRANSPORTATION}

Travel and transportation into, within, and out of the upper Capibaribe basin are by highway, there being neither railroad nor airline service within the basin. The nearest railroad shipping point is at Caruaru. Local products move to Caruaru or to other markets outside the basin by truck. Public transportation to many cities and towns within the basin is provided by buslines.

The populous northeastern part of the area has access to Recife via State Highway PE 5, which leares the area at Limoeiro. This highway is paved from Vertentes to Recife. The central and western parts of the basin have access to Caruaru, the second largest city in Pernambuco, by way of National Highway BR 104. The southern $19 \mathrm{~km}$ of BR 104 is paved. Near Caruaru this highway joins Nationsl Highway BR 238, a major east-west highway that is paved eastward to Recife and westward to the vicinity of São Caitano. Northward, Highway 
BR 104 affords communication with Campina Grande, the second largest city in the Estado de (state of) Paraíba. The northern part of BR 104 within the Capibaribe basin is not paved.

Riacho das Almas, the major town in the southeastern part of the area studied, is connected with Caruaru by an unpaved road, passable in all seasons. Jataúba, Brejo da Madre de Deus, Fazenda Nova, and Carapotós are connected by an unpaved but usually passable road that joins Highway BR 104 about $12 \mathrm{~km}$ south of Toritama. Other places in the basin are accessible by a network of secondary roads, some of which become virtually impassable in the wet season.

\section{ECONOMIC DEVELOPMENT}

The economy of the upper Capibaribe basin is dominantly agricultural. Cattle raising is the major economic activity throughout the basin, and milk production is important in the eastern part, especially near Vertentes, Surubim, and Bom Jardim, whence the mill" can be promptly transported by good highway to Recife. Next in importance is cotton, which is grown for both fiber and seed. The seed is pressed into cottonseed cake in factories at Pão do Açucar and Limoeiro for use as cattle fodder, supplementing a succulent spineless cactus called palma. The palma is usually grown in the same fields as the cotton, in alternate rows. Among the other agricultural products of the area are mandioca, beans, corn, and the nut of the castor bush. Coffee, bananas, and pineapples are important crops at a few places where the precipitation suffices, as at Taquaritinga do Norte.

Forest products are restricted to charcoal, which is produced throughout much of the wooded areas. Lime is produced frcm a few small deposits of limestone, which is burned locally in small furnaces. Among the industries of the area are pressing cottonseed cake, tanning, leatherworking, and furniture making.

\section{GENERAL GEOLOGY OF UPPER CAPIBARIBE FASIN}

Consolidated igneous and metamorphic rocks underlie thl entire upper Capibaribe basin; saprolite overlies the consolidated rock at most places; and alluvial sediments occupy the lower parts of the valleys. The consolidated rocks are granite, gneiss, schist, and related rock types of Precambrian age, which commonly are grouped together under the term "crystalline rocks." They are intricately folded at many places, have been faulted, and are dominated structurally by an overthrust fault. The saprolite is not continuous throughout the basin, being interrupted where ridges and mountains of bare consolidated rock protrude. The alluvium is less extensive than the weathered rock. 
The geology of the basin is best understood in relation to the geology of the region.

\section{REGIONAL GEOLOGY}

Relatively little has been published about the geology cf the upper Capibaribe basin, but several authors have discussed various aspects of the geology of northeast Brazil, of which the upper Capibaribe is part. Much remains to be done, as much is imperfectly understood. Stratigraphic relationships have been established only for large groups of rocks, and some of these are disputed. Broad structural trends have been recognized, but the details of geologic struture have been investigated only locally. The historical development of ideas on the geology of northeast Brazil is suggested by the following outline, which provides the framework into which the upper Capibaribe basin is to be fitted.

Branner (1902) divided northeast Brazil into two geologic provinces, the sedimentary coastal belt and the Cryptozoic interior.

Crandall (1910), who is called the founder of Precambrian geology of northeast Brazil, recognized the following four series of rocks: (1) Basement crystalline complex of gneiss and schist, (2) Ciará Series, made up of schist, quartzite, and marble, (3) sandstone, shale, and limestone, and (4) lacustrine deposits and limestone deposi's and limestone of recent origin.

Oliveira (1923), when studying the copper deposits of Pedra Branca, observed certain similarities with the ferriferous formations of the Estado de Minas Gerais and on this basis assigned the Ceará Series to the Algonkian.

Williams (1926) found that rocks of the Ceara Serie in ridges around some of the granitic massifs in the northern part of the Estado de Ceará had been deformed, seemingly by the intrusion of the granite.

Oliveira and Leonardos (1943) noted that, in various small areas in the northeast, the Precambrian includes phyllite, schist, quartzite, and marble, which had been described by Crandall under the name Ceará Series.

Rolff (1945a) classed as Proterozoic all the rocks previously considered to be Cryptozoic and distinguished granites of thre? ages. One of these he considered to be responsible for gneissification of the Ceará Series. In 1947 he pointed out that one of the leading characteristics of the Planalto da Borborema is the presence of abundant basic eruptive rocks.

Ebert $(1955 ; 1962$; oral commun., 1960) regarded the geologic structure of northeast Brazil as less complicated than that of the Estado de Minas Gerais, which he had studied. The metamorphism is compli- 
cated, but the stratigraphy is relatively simple. He recognized the following sequence, in ascending order : unnamed rocks, Equador Formation, Parelhas Group, and Quixaba, Florânia, and Seridó Formations (table 1). The Seridó, which had been named by L. S. de Moraes, is the most widely distributed of these units. The Parelhas is variable in thickness, but east of the town of Parelhas it is more than $100 \mathrm{~m}$ thick. A major discordance separates the Equador from the rnnamed rocks. The youngest rocks are granite and pegmatite, founc' by the potassium-argon method to range in age from 1,100 down to 500 million years old.

TABLE 1.-Geologic formations of northeast Brazil according to Elert (oral commun., 1960)

[Formations recognized in the upper Capibaribe basin are underlined]

\begin{tabular}{|c|c|c|c|c|}
\hline Era & System & Series & Unit & Description \\
\hline \multirow[t]{3}{*}{ Cenozoic } & Quaternary & $\begin{array}{l}\text { Pleisto- } \\
\text { cene }\end{array}$ & $\frac{\text { Alluvium }}{\text { and }}$ & $\begin{array}{l}\text { Sand, gravel, boulders. } \\
\text { Sand, gravel, earthy limonite. }\end{array}$ \\
\hline & \multicolumn{4}{|c|}{ Unconformity } \\
\hline & $\begin{array}{l}\text { Lower Tertiary } \\
\text { Upper Cretaceous }\end{array}$ & & $\underset{\text { São Martins Forma- }}{\text { tion }}$ & $\begin{array}{l}\text { Sand, sandstone, eart'iy limonite. } \\
\text { kaolin. }\end{array}$ \\
\hline Mesozoic & & & Unnamed & Diabase. \\
\hline
\end{tabular}

Unconformity

\begin{tabular}{l|l|l|l|l}
\hline Paleozoic & & Ennamed & Granite, gabbro. \\
\hline
\end{tabular}

Unconformity

\begin{tabular}{|c|c|c|c|c|}
\hline \multirow{7}{*}{ Precambrian } & \multirow{5}{*}{$\begin{array}{c}\text { Upper } \\
\text { Precambrian }\end{array}$} & \multirow{5}{*}{ Ceará } & Seridó Formation & $\begin{array}{l}\text { Mica schists with garnet, partly } \\
\text { quartzitic, with a fev intercalated } \\
\text { scarnites. }\end{array}$ \\
\hline & & & Florânia Formation & $\begin{array}{l}\text { Metagraywacke, paragneiss, meta- } \\
\text { arkose, quartzite, epidote-quartz- } \\
\text { ite. }\end{array}$ \\
\hline & & & Quixaba Formation & $\begin{array}{l}\text { Crystalline limestone, scarnite, para- } \\
\text { amphibolite, mica schist. }\end{array}$ \\
\hline & & & Parelhas Group & $\begin{array}{l}\text { Paragneiss, metaarkose (partly con- } \\
\text { glomeratic), mica schist, meta- } \\
\text { graywacke, metaconglomerate, ita- } \\
\text { birite. }\end{array}$ \\
\hline & & & Equador Formation & $\begin{array}{l}\text { Muscovite quartzite partly conglom- } \\
\text { eratic or arkosic. }\end{array}$ \\
\hline & & & Unconformity & \\
\hline & $\begin{array}{c}\text { Lower } \\
\text { Precambrian }\end{array}$ & & Unnamed rocks & $\begin{array}{l}\text { Migmatite, orthogneiss, paragneiss, } \\
\text { amphibolite. }\end{array}$ \\
\hline
\end{tabular}


Ebert subdivided the Precambrian rocks into older (Archean) and younger (Algonkian) at the unconformity noted above. AJthough both sequences include the same rock types, each has distinguishing characteristics. The older sequence contains many types of bas: magmatic rocks, and most exposures include intermediate rocks of supracrustal or abyssal origin, which make resistant amphibolite bodies that are recognizable even where intensely migmatized. The sequence contains little quartzite or carbonate rock.

The younger Precambrian rocks, on the other hand, contain extensive metasedimentary beds amenable to stratigraphic subdivision. The folds in this sequence indicate considerable compressior. The anticlines are sharply crested and have granitized or migmatized cores. The synclines generally have vertical axes, or have the form of a fan but without curvature.

The correlation of the Precambrian rocks has rested hervily on the degree of metamorphism of the rocks because regional geologic mapping remains inadequate, but such correlation invites error. The highly metamorphosed rocks are considered to be older than the less metamorphosed rocks, but this relationship is not everywhere true. At places, a higher degree of metamorphism has been found in the upper rocks than in the lower (older) ones.

\section{PRECAMBRIAN ROCKS}

The geologic investigation and mapping in the upper Capibaribe basin and the description herein refer mainly to the part wost of long. $36^{\circ}$. Mapping in the eastern part was hampered by inadequacies of the available base map and lack of aerial photographs. Moreover, the rocks in the east are deeply weathered and therefore are generally covered by saprolite, which reduces the opportunities to study them. Geologic reconnaissance indicated a predominance of highly altered biotite schist in the bedrock of the part of the upper Capikaribe basin east of long. $36^{\circ}$. Between Rafael and Chicão, schist is interbedded with gray paragneiss and lenticular crystalline limestone. The limestone is being quarried at Chicão. Altered gneisses are common between Chicão and Riacho das Almas, but schists predominate in the eastern part, in the vicinity of Ameixas, Várzea Escondida, Cumaru, and Passira, and in the north, in the vicinity of Surubim, Carinhas, and Tamboatá.

The rocks in the Capibaribe basin west of long. $36^{\circ}$ (approximately west of Toritama) are abundantly exposed in ridges ard hills, in stream-beds, and in fields. Their steep slopes and odd shares give the topography a character which, though doubtless approximated elsewhere, is distinctive. The rocks can be divided into two groups, the 
migmatites and the metasediments (ectinites). The migmatites are much folded and faulted. The metasediments are folded into anticlines and synclines. The principal constituent minerals in these rocks are quartz, feldspar, and mica (both biotite and muscovite). The granites weather by exfoliation, and blocks as large as house: become rounded like boulders. The metasediments, on the other hand, tend to break down into slabs and plates along planes of weakness of schistosity. The crystalline rocks were studied both at the outcrop and by thin section. The thin sections served to verify the field ident:fications of the rocks and to provide detailed data on their mineral composition. The principal rock types in the migmatite group are migmatite, granite, and mylonite, described in the following paragraphs.

The migmatite is an extremely hard rock, although at many places superficially altered, and is composed principally of biotite, white feldspar, and quartz. It occurs near Jataúba, Poço Fundo, Fará, and locally near Fazenda Nova. The rock is characterized by $\Sigma$, banded structure due to the alternation of thin layers of light and dark minerals. The bands average $10 \mathrm{~cm}$ (centimeters) in thickness and at many places extend the full length of an exposure, exhibiting many small-scale folds. Such folding can be seen at the places previously named. Evidently, these rocks were subjected to intensive metamorphism.

Granite occurs as granite porphyry and as medium-grained calcalkaline granite. The porphyry occurs in the Fazenda Nova-Nas aró area and is characterized by phenocrysts of microcline up to $6 \mathrm{~cm}$ long in a matrix of microcline, quartz, and biotite of approximately uniform grain size. The rock includes many dark xenoliths and at places is cut by veins of fine-textured granite. The medium-grained granite is dominant in the area of Brejo da Madre de Deus and Serra do Ve'tto, typically is gray, is cut by aplite dikes, and includes dark xeno'iths.

Mylonite occurs at Apolinário, where it forms a low escarpment. It is about $500 \mathrm{~m}$ thick and extends laterally about $6 \mathrm{~km}$. At A polinário the structural lines are abruptly twisted and the rocks are broken and laminated. They have pronounced lineation and an aphanitic texture.

The metasedimentary rocks were originally clastic, excert for the crystalline limestones. The following rock types were identifed:

Migmatitic biotite gneiss, dark-colored, very hard, medium- to coarsegrained; composed of plagioclase, potash feldspar, quartz, hornblende, and biotite, with kaolin and sericite resulting from alteration of the feldspars; in microscopic examination a cataclastic texture is apparent.

Biotite-garnet paragneiss, light-gray, fine-grained; composed principally of quartz, feldspars, biotite, and garnet; biotite is the only mafic 
mineral, and the garnet, which occurs as phenocrysts, formad at the expense of the biotite.

Gneiss, formed by cataclastic metamorphism, composed $o^{f}$ quartz, feldspar, and biotite; principal feldspars are microline and acidic plagioclase, the latter being the most abundant feldspar.

Biotite paragneiss, light-gray ; porphyritic-gneiss structure, cornposed of quartz, pink feldspar, and muscovite, rare garnet; grenoblastic texture.

Muscovite paragneiss, whitish-gray ; gneissic-schistose structrre; composed principally of quartz, pink feldspar, and muscovite.

Biotite schist, dark gray, fine- to medium-grained; cut by vains consisting predominantly of quartz and feldspar-biotite; at places, as at Fazenda Barra, this rock is enriched in feldspars and could be called biotite-feldspar schist.

Mica schist with garnet, dark-gray; fine- to medium-graine- garnet crystals as much as $1 \mathrm{~cm}$ in diameter.

Metaarkose, whitish-gray ; gneissic structure, fine- to medium-grained; composed principally of white feldspar and a lesser amount of quartz.

Quartzite, yellowish-white, fine- to medium-grained; breaks into plates or slabs; composed principally of quartz and a lesser arount of feldspar.

Crystalline limestone, white or bluish-white, in lenses of irregular thickness.

Two major rock units are recognized in the upper Capibrribe basin. These are separated by a discordant contact marked by a thrust fault striking approximately east-northeast-west-southwest acrcss the area, as shown on plate 1. This fault is described in the section on structural geology. The overthrust block (south of the fault trace) is a complex of such rocks, chiefly migmatites and granites so interbedded and repeated that they cannot be separated in mapping. They are, in all probability, the oldest rocks and therefore are considered to date from early Precambrian time.

The underthrust block (north of the fault trace) is comrosed of the folded metasediments already described, predominantly biotite paragneiss, muscovite gneiss, biotite schist, and metagraywacke. These rocks are the Quixaba and Florânia Formations of Ebert, are younger than the migmatites and granites, and therefore ar' 9 regarded as upper Precambrian in age (table 1). Ebert's criterion for separating the two has been followed in the upper Capibaribe basin, namely, that the calcareous lenses belong just below the top of the Quixaba Formation.

STRUCTURAL GEOLOGY

Three major orogenies are recognized in the western part of the upper Capibaribe basin, the latest being the overthrusting th at brought about the dominant structural feature of the area. 
The first orogeny recognized in the Capibaribe basin affected the lower Precambrian rocks and led to their metamorphism. As evidence, it left structural lines, or lineations, in the migmatites. There lineations can be seen in the vicinity of Fazenda Nova and Brejo da Madre de Deus. When examined on aerial photographs, they are seen to be abundant in some localities but scarce in others and to bend abruptly at places, thus reflecting the nature and the greater or lesser intensity of the forces to which the rocks were subjected.

The second orogeny affected principally the metasediments, folding them into anticlines and synclines whose axes strike in various directions and at places change direction. Near Campos, for example, an anticline and syncline have axes striking northeast-southwest but gradually veering to east-west.

A small anticlinorium, made up of a syncline between two anticlines, occupies the region from Poço Fundo northeastward to Cacimba de Baixo. The axis of the main anticline in this structural group passes close to Poço Fundo and is here called the Poço Fundo anticlino (pl. 1). It strikes northeast-southwest, plungs about $20^{\circ} \mathrm{SW}$ and is assymetric. Its core is strongly migmatized, and its limbs form scarps. Its west limb is vertical and underwent minor compression, causing small scarps in the migmatitic rocks, which are rather uniformly oriented and have been folded and faulted by later forces. These forces affected part of the migmatized core and are expressed in the Poço Fundo area by east-west structural lineations. The east limb of the main anticline was strongly compressed and, in addition to small scarps in migmatite, has two folds of lesser amplitude superimposed on it. The axes of these two folds pass east of Poço Fundo and extend to the vicinity of Cacimba de Baixo. There the structural lineation is well formed, indicating that large-scale forces operated in the southeast-northwest direction. In the west limb, on the other hand, the forces were of smaller amplitude and operated north-south and northeast-southwest.

Northward, the axis of the main Poço Fundo anticline vers to an east-west strike; and the structural lineations and the axes of other folds, which cross the road diagonally from Santa Cruz do Crpibaribe to Pará, trend similarly. This change of direction probably reflects the influence of later forces operating in the north-south direction. One effect of these forces was to compress the structural lineations. Another was to raise the metamorphic grade, producing migmatized gneisses, for example.

Structural lineations north and northeast of Jataúba strike approximately east-west, but have abrupt changes in direction and are much broken by small transverse faults, which can be seen in the first 
escarpment of the Serra dos Umburanas. Apparently the forces causing this faulting operated in a north-south direction.

Two symmetrical folds-an anticline and syncline-with parallel axes striking approximately northeast-southwest, occur along the road that runs west and then northwest from Gravatá de Jaburu. The rocks seen at the outcrop, among them migmatite and migmatitic gneiss, have been intensely metamorphosed. Granite occupies the core of the anticline.

Small secondary folds, or wrinkles, in schistose rocks that have dips of $15^{\circ}$ to $20^{\circ}$, occur in the vicinity of Taquaritinga do Norte, Gravatá de Jaburu, and Maracá.

The third orogeny to affect the area resulted in a great thrust fault, first observed in the Serra da Taquara (north of Taquaritinga do Norte) and vicinity by Ebert (1962). This is the first overthrust structure to be observed in the northeast. Rocks of early Precembrian age were thrust over those of late Precambrian age. The trace of the fault strikes approximately east-northeast-west-southwest near Taquaritinga do Norte, Santa Cruz do Capibaribe, Apolináro, an 7 Passagem and coincides, approximately, with the contact between tho lower and upper Precambrian groups. Existence of this fault is bised on the following considerations :

1. Ebert's stratigraphy places the metamorphosed rocks, such as migmatites and migmatitic gneisses, in the lower Precambrian and the metasediments in the upper Precambrian.

2. The younger rocks dip under the older ones. The angles of dip differ from one place to another, probably because of the uneven resistance offered by the upper Precambrian rocks. Thus from Apolinário to Santa Cruz do Capibaribe, the dips in the lower Precambrian rocks are subvertical, for in this stretch the gneiss and migmatities are very resistant, whereas between Taquaritinga do Norte, Gravatá de Jaburu, and Maracá, where schists rich in bijtite, already somewhat altered, are predominant, the dips are low, being generally between $15^{\circ}$ and $20^{\circ}$ and at some places even zero.

3. The fault plane dips southwest about $15^{\circ}$ and can be seen in the Serra de Taquaritinga. It is well formed, also, between the towns of Taquaritinga do Norte and Vertentes.

4. Two fensters, the result of eroding away the lower Precambrian, occur in the area of Tortiama, Socorro, and Pão de Açucar.

5. Scarps in the overthrust block, that is, in the lower Precambriar rocks, occur at various places along the contact. They make small granitic or migmatitic ridges between Apolinário and Santa Cruz do Capibaribe. Near A polinário the fault is characterized by the presence of mylonite and by a sharp northwest bending of the structural lineations that come from the southwest. 


\section{CENOZOIC ROCKS}

\section{SAPROLITE}

Saprolite, also called eluvium, is decomposed rock that has not been transported. It forms as a result of weathering of the parent rock. Rainwater picks up carbon dioxide while passing through the atmosphere and humic acid and other substances while passing through the soil. These then dissolve some of the minerals of the rock when the water seeps into crevices. The roots of plants help by wedging into cracks and spreading them apart as they themselves grow. The loose material formed by this process normally is coarse grained at the bottom, where it grades into the bedrock, and fine grained, even clayey, near the land surface. Saprolite accumulates to thicknesses cf several meters, even tens of meters, where protected from erosion, but at other places is removed as rapidly as it is formed, so that the rock is left bare.

Little is known about the thickness of the saprolite at most places in the upper Capibaribe basin, because few wells have been dug or drilled through it. Where rock exposures are numerous and loose rocks are scattered about in the fields, as in the western part of the kasin, the saprolite probably is relatively thin. Where rock exposures and loose rocks are scarce, the saprolite may be many meters thick. The saprolite is not identified on plate 1, because it and the bedrock cannct, both be shown on the same map. The saprolite occurs throughout the basin and is of geologically recent origin, although the parent rock from which it is derived is ancient. It is approximately contemporaneous with the alluvium.

\section{ALIUVIUM}

Alluvium consists of gravel, sand, silt, and clay deposited in the lower parts of the valleys by streams. The layers of alluvium are irregular, becoming thicker or thinner within short distances laterally and gradually changing in texture. A layer may consist exclusively of sand at one place but grade into gravel in one direction and into clay in the opposite direction. Where alluvium consists exclusively or principally of sand or gravel, it is usually permeable, and, if saturated, will yield water readily to wells. Where it consists of silt or clay, or of mixtures of silt or clay with sand or gravel, it usually has low permeability and will yield only small amounts of water or none at all. It usually is not possible to determine from evidence at the land surface what proportion of the alluvium at any particular place is permeable. For this reason, test holes to determine the thicknessas of sand and gravel often are drilled when sites for large and expensire wells in alluvium are to be selected. 
Alluvium is present in the valleys of the upper Capibrribe basin, but its volume is small in relation to the size of the basin. Even along the Rio Capibaribe itself, the width of the alluvium is generally not more than a few hundred meters; the thickness is probably less than $5 \mathrm{~m}$. The width and thickness of the alluvium become less in the upstream direction and along tributaries. The alluvium along tributaries and in the headwaters generally is so thin that it contains water only temporarily in the wet season. At places, even along main streams, the bedrock crops out in the channel, interrupting the continuity of the alluvial deposit longitudinally along the valleys.

To determine whether the alluvium is water bearing and whether it might contain an aquifer capable of supplying the water needed by a small town, four drive-point wells were put down at Jataúba (fig. 1). In such testing, the drive point may stop on a large pebble, cobble, or boulder instead of the bedrock under alluvium, leaving doubt as to the true thickness of the alluvial deposit. The results of this testing, however, often suggest the minimum thickness of the allurial deposit and whether there is a water supply worth developing.

The drive-point wells ranged from 2 to $4 \mathrm{~m}$ in depth. T. e data are insufficient for estimating average thickness, but they suggest that the sandy alluvium of the riverbed may be $4 \mathrm{~m}$ thick and has a saturated zone about $3 \mathrm{~m}$ thick.

The alluvium along the Rio Capibaribe is likely to be similar to that at Jataúba, though possibly becoming progressively finer grained in the downstream direction and differing greatly in details of stratification. In general, the wider the flood plain along the river, the thicker the alluvium is likely to be. This criterion, however, is not infallible.

Water occurs as atmospheric moisture and as precipitation, flows in streams, is temporarily stored while slowly moving through reservoirs, both on the land surface and underground, is stored likewise 


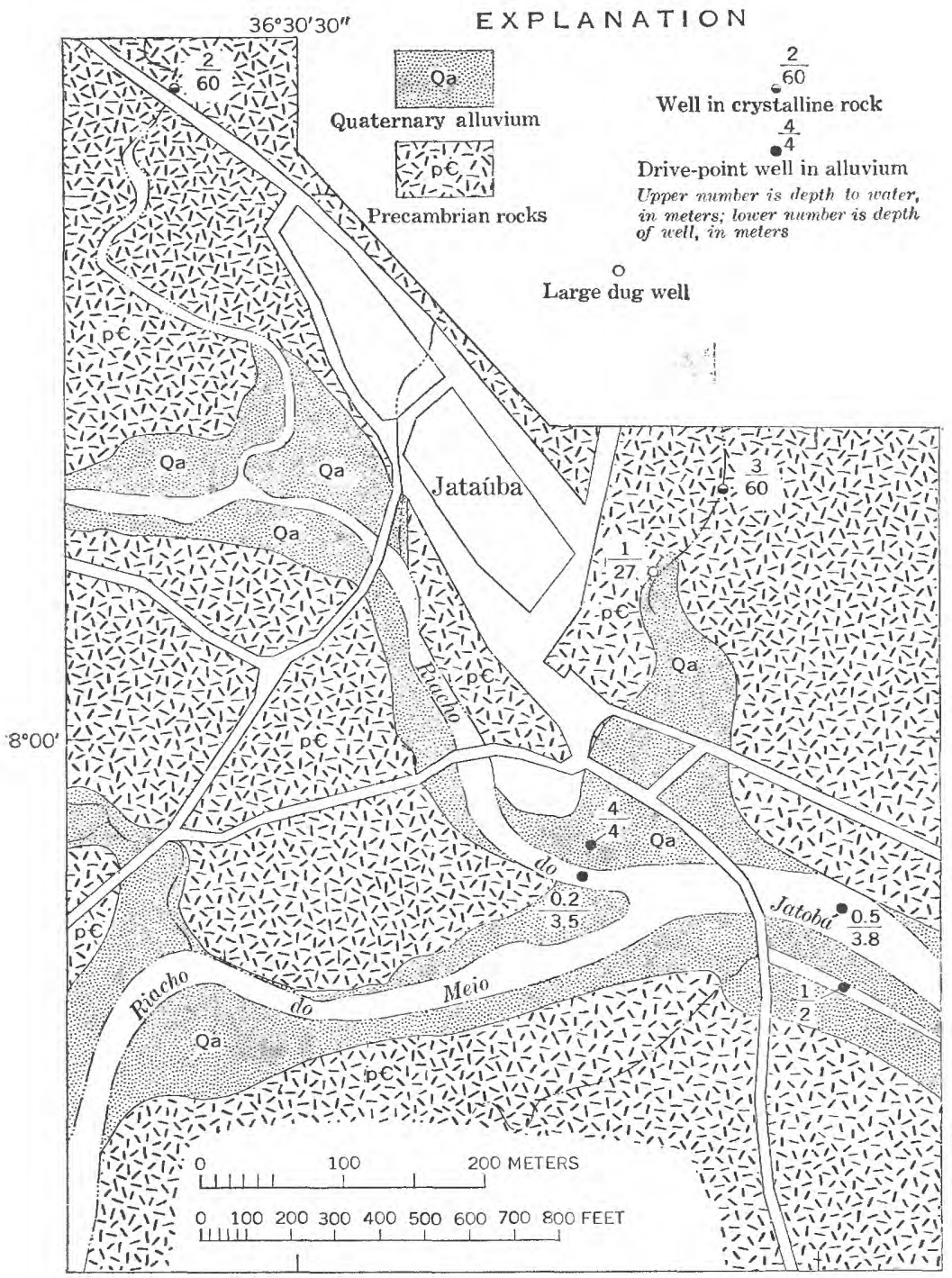

Frgore 1.-Locations of wells at Jataúba. 


\section{HYDROLOGY}

in lakes and oceans, and is evaporated from water and land surfaces into the atmosphere. Changing form and nearly always moving, it is a prisoner in the hydrologic cycle, sometimes completing the full cycle-sea to atmosphere to land to sea-but more often repeating small cycles within the major cycle. The activities of man change details in the major cycle, as by locally retarding or hastening the flow, or by increasing the evaporation, but they do not destroy the cycle or the water.

The activities of man with respect to water must be adjusted to the hydrologic cycle if they are to succeed. An evaluation of the water resources of an area, therefore, should include examination of the various aspects of the hydrologic cycle that operate in the area. Among these are the precipitation, evaporation, transpiration, infiltration, and underground storage. Also important are the effect of topography and relief of the land on streams and the effect of soil and rocks on the relative magnitude of runoff. Where the demand for water is small, as in the upper Capibaribe basin, it is often unnecessary to measure carefully all the different parts of the cycle. It may suffice to identify the places in the cycle where water can be diverted in sufficent quantity to meet existing needs and to relate these places, in general terms, to the cycle as a whole. Where a major diversion of water is planned, however, the quantities need to be measured accurately; and the probable disturbance caused by withdrawing water should also be appraised.

\section{SURFACE WATER}

The streams that drain the upper Capibaribe basin are intermittent and are subject to wide variations in volume in response to precipitation or lack of it. Flow ceases soon after the end of the rainy season because the soil and rocks have only small storage capacity and the water accumulated in them soon drains away into the streams. Thus, floodflow is a large percentage of the total streamflow, and base flow is but a small percentage.

The quantity of water flowing out of the basin can only be approximated because the records of streamflow are short and incomplete. The Departamento Nacional de Obras de Saneamento has gaged the Rio Capibaribe at Toritama since 1954 and at Limoeiro since 1956. Gage heights have been recorded twice daily, but rating curves for the stations have not been established. The gage readings were used in this 
study to determine the cross-sectional area of the river, which, multiplied by the velocity as determined from the Chezy-Manning formulas, ${ }^{3}$ yielded the discharge curves illustrated in figure 2. These curves, although crude, provide a basis for estimating the total flow for 1964, which at Toritama was about 560 million $\mathrm{cu} \mathrm{m}$ (cubic meters) and at Limoeiro was about 2,000 million $\mathrm{cu} \mathrm{m}$. These figures indicate that the flow at Limoeiro is more than five times the flow at Toritama. Nevertheless, the river often is dry, even at Limoeiro, after several months of dry weather.

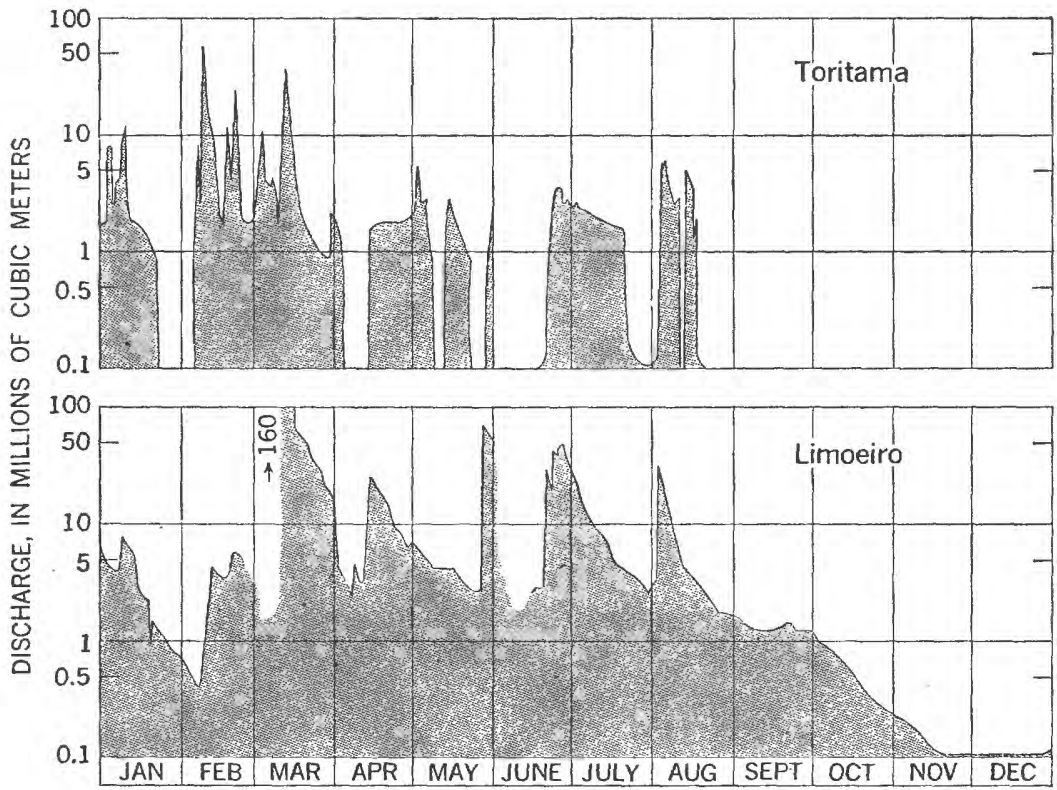

Figure 2.-Daily streamflow at Toritama and Limoeiro in 1964.

The streams rise promptly after rains of sufficient magnitude to cause runoff and then recede almost as rapidly. At both Toritama and Limoeiro, the sharp peaks and valleys of the hydrographs suggest the flashy character of the streamflow and the small capacity of the ground-water reservoir.

3 Chezy formula (Corbett and others, 1943, p. 81-83): $V=C \sqrt{R S}$, where $V$ is velocity in meters per second, $S$ is the slope or energy gradient, $R$ is the hydraulic radius in meters, and $C$ is a coefficient depending principally on the roughness of the channel, and the hydraulic radius as determined from the Manning formula, which is: $C=\frac{1.486}{n} R$, where $n$ is the coefficient of roughness as proposed by Horton (1916, p. 373, 863). 
Flow measurements made with a pygmy current meter on the Rio Capibaribe between July and October 1964 near Apolinário, near Poço Fundo at Toritama, near Tapada, and on five tributaries suggest the magnitude of the flow in several streams during the latter part of a wet season (pl. 1 and table 2). The maximum, expectably, was on the Rio Capibaribe at Tapada, the station farthest downstream, and amounted to $1.85 \mathrm{cu} \mathrm{m}$ per second. The lowest recorded at the same station was $0.8 \mathrm{cu} \mathrm{m}$ per second. The minimum at any location was zero, recorded as "dry" on October 8 on the Capibaribe at Poço Fundo and on Riacho Tapada.

TABLE 2.-Flow in Rio Capibaribe and five tributaries on selected dates in 1964, in cubic meters per second

[Measurements made by pygmy current meter]

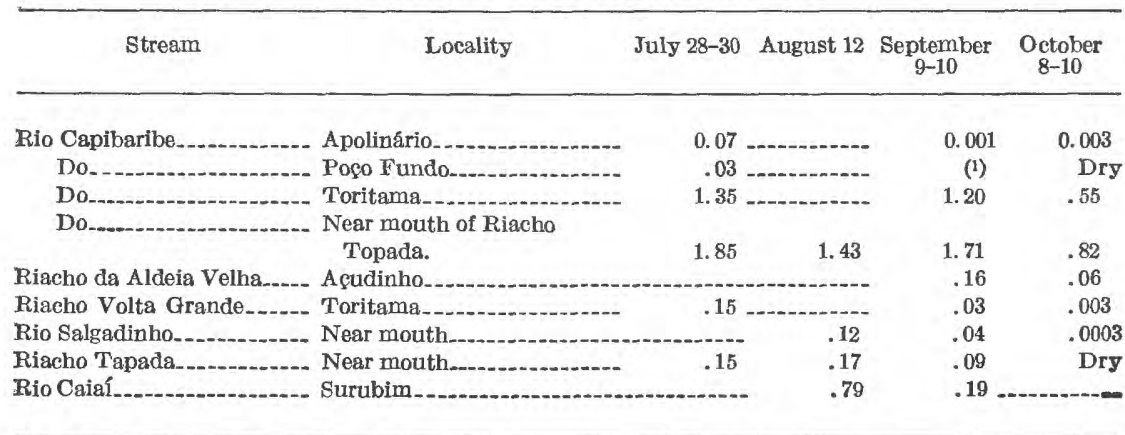

1 Pools in channel, but no flow.

The average annual runoff from the basin cannot be estimated because of inadequate data, but the variation in runoff from year to year probably is rather large. The variations in annual precipitation suggest that the maximum runoff from the upper Capibaribe basin may be twice the minimum.

A valid long-term water budget for the upper Capibaribe basin cannot now be established, but the budget for 1964 suggests how the precipitation is distributed. The year 1964 was the first year of operation for the precipitation stations shown on plate 1 . From the records obtained, it is estimated that 4,733 million cu $\mathrm{m}$ of water fell in the upper Capibaribe basin in 1964 . Over 60 percent of this fell in the part of the basin between Toritama and Limoeiro, and the runoff from this sector was about 80 percent of the total passing Limoeiro. In the basin above Toritama, however, evaporation and underground storage together accounted for about two-thirds of the water that fell. The estimated quantities of water are shown in table 3. 
TABLE 3.-Estimated precipitation, runoff, and storage and evaporation, in millions. of cubic meters, in the upper Capibaribe basin, 1964

\begin{tabular}{|c|c|c|c|}
\hline Budget eategory & $\begin{array}{c}\text { Above } \\
\text { Toritama }\end{array}$ & $\begin{array}{l}\text { Between } \\
\text { Toritama an } 1 \\
\text { Limoeiro }\end{array}$ & Total \\
\hline $\begin{array}{l}\text { Precipitation } \\
\text { Runoff } \\
\text { Evaporation and underground storage....... }\end{array}$ & $\begin{array}{l}1,700 \\
500 \\
1,200\end{array}$ & $\begin{array}{l}3,000 \\
2,209 \\
80 ?\end{array}$ & $\begin{array}{l}4,700 \\
2,700 \\
2,000\end{array}$ \\
\hline
\end{tabular}

\section{GROUND WATER}

The ground water in the upper Capibaribe basin originates in the precipitation that falls in the basin. Some precipitation begins to infiltrate early in the rainy season, after the immediate water needs of the vegetation and the moisture deficiency of the soil hove been satisfied. The water entering the ground moves down the gradient, from places of high head to places of low head, but difference in head is not the only factor controlling its movement. Also very important is the permeability of the soil and rock of the locality. A rock or soil that is permeable with respect to water has a texture that will permit water to pass through it in response to natural differences in head, that is, under a natural hydraulic gradient. Permeability deronds on porosity, which is the amount of unoccupied space within the rock or soil, and on the size of the spaces and the manner in which they are connected. The permeability that is inherent in the texture of a rock or soil is called primary permeability, as opposed to stcondary permeability, which is created by fractures or cavities formad after solidification of the rock. The permeability of unconsolidated materials, such as soil and alluvium, is principally or entirely primary permeability; that of crystalline rocks, such as granite and gneiss, is almost entirely secondary permeability; and that of some consolidated sedimentary rocks, such as some sandstones, is both primary and secondary.

\section{WATER IN PRECAMBRIAN CRYSTALIINE ROCKS}

The crystalline rocks of Precambrian age that compose the bedrock of the upper Capibaribe basin have principally seconds.ry permeability, which for practical purposes is negligible. Where these rocks are much fractured and deeply weathered, they may contain considerable water, but where unbroken they contain practically none. Fractures develop in them along zones of weakness; and although the zones themselves may extend to considerable depth, the fractures generally are not open very far below the zone of weathering. For this reason, the capacity of crystalline rocks to contain and transmit water diminishes rapidly with increasing depth. 
Fracture zones have limited usefulness as reservoirs for water. Although fractures may extend many kilometers, they are linear features having only small width, and, consequently, only small area. They may, or may not, connect with other fractures. They are not necessarily open, but may be partly or entirely filled by weathered rock material, gouge, or mineral deposits.

Fractures generally are most numerous in topographically low areas because they have largely controlled erosion and have determined the locations of streams. This is fortunate, because the low areas collect the runoff and therefore are the areas most likely to have water to feed the fractures. The fractures, however, affect only a relatively small part of the rock; they do form reservoirs for storage of ground water, but many of them are small in total capacity. They may constitute a chain of small reservoirs, which quickly fill with water at the onset of a rainy season; spill surplus water from ono to another down gradient; and then, through the dry season, gradually yield their small store of water to springs and to evaporation and transpiration. A well in such a reservoir may seem to have tapped an abundant water supply because water drains rapidly into it from open fractures, but it may prove to be of only temporary or seasonal use, if the total volume of water-filled fractures is small.

A regional pattern of ground-water movement cannot exist in fracture zones, because movement in many directions is obstructed by solid rock. The water can only follow the fractures or fracture system. The circulation of the ground water in such a reservoir consists of infiltration (recharge) from the land surface and movement through the fractures to places of discharge, commonly in springs or seeps. The discharge may also be effected by evaporation. Circulation thus is restricted to narrow zones, generally within range of evaporation and the roots of phreatophytic plants. Deep circulatior of ground water within and between fracture-type reservoirs is gen rally small because of the tendency of fractures to close at depth.

\section{WETL-DRILLING OPERATIONS IN PRECAMBRIAN ROCKS}

The Departamento Estaudal de Poços e Açudagem de Pernambuco inaugurated late in 1964 a program of drilling water wells for small towns in the interior of the State, including 16 wells for the upper Capibaribe basill. The work was done by a commercial welldrilling company under contract to the State of Pernambuco. Percussion equipment was used exclusively. The wells were to be equipped with windmills. 
The Divisão de Hidrogeologia of the SUDENE was requasted to select the sites for the wells in the upper Capibaribe basin; and the task of selecting them was given to the authors of this report, who thus had the opportunity to apply geologic criteria to the selection of well sites. The principal drawback was the requirement that the wells be located near towns. This was in accordance with the objectives of the State, but it restricted the possibilities open to the geologists and may have caused the selection and drilling of some less than favorable sites.

All the wells were to be drilled into the crystalline rocks; their locations, therefore, were based on the probability of secondary permeability consisting principally of fractures. The possibility that the fracture zones intercepted by the well would prove to be filled with impermeable materials was a risk accompanying the selection of each site. The locations of the wells are shown on plate 1 , and the results are summarized in table 4.

WELL DISCHARGE

The wells described in table 4 were tested by pumping for 24 hours with a cyclinder pump driven by a gasoline engine if the water supply was abundant, or by bailing until dry if the water supply was meager. The drawdown of water level in the wells was measured after the pumping stopped, but, for many wells, was limited by the depth of the pump intake. Where the tests were made by bailing, the only possible measurement of drawdown had to be made after the bailer was withdrawn for the last time.

The maximum discharge obtained from the wells tes'ed was $9,600 \mathrm{l} / \mathrm{hr}$ (liters per hour) and the minimum, in three wells, was zero. The discharges reported in table 4 are the discharges at the end of $24 \mathrm{hr}$, for the wells that could be pumped that long, not the initial discharge, which usually was greater. Of 16 wells, 11. yielded $1,000 \mathrm{l} / \mathrm{hr}$ or more, averaging about $5,000 \mathrm{l} / \mathrm{hr}$. Two others yielded useful quantities, but less than $1,000 \mathrm{l} / \mathrm{hr}$.

The low yields of the wells drilled in the upper Capibaribe basin are about what can be expected from the prevalent rock trpes and correspond to experience elsewhere in northeast Brazil. Tl a yields are sufficient for the intended purpose, that is, supplying water for cattle.

AQUIFER TESTING

The aquifer characteristics measured by pumping tests in wells usually cannot be determined for fractured rocks because the porosity, 


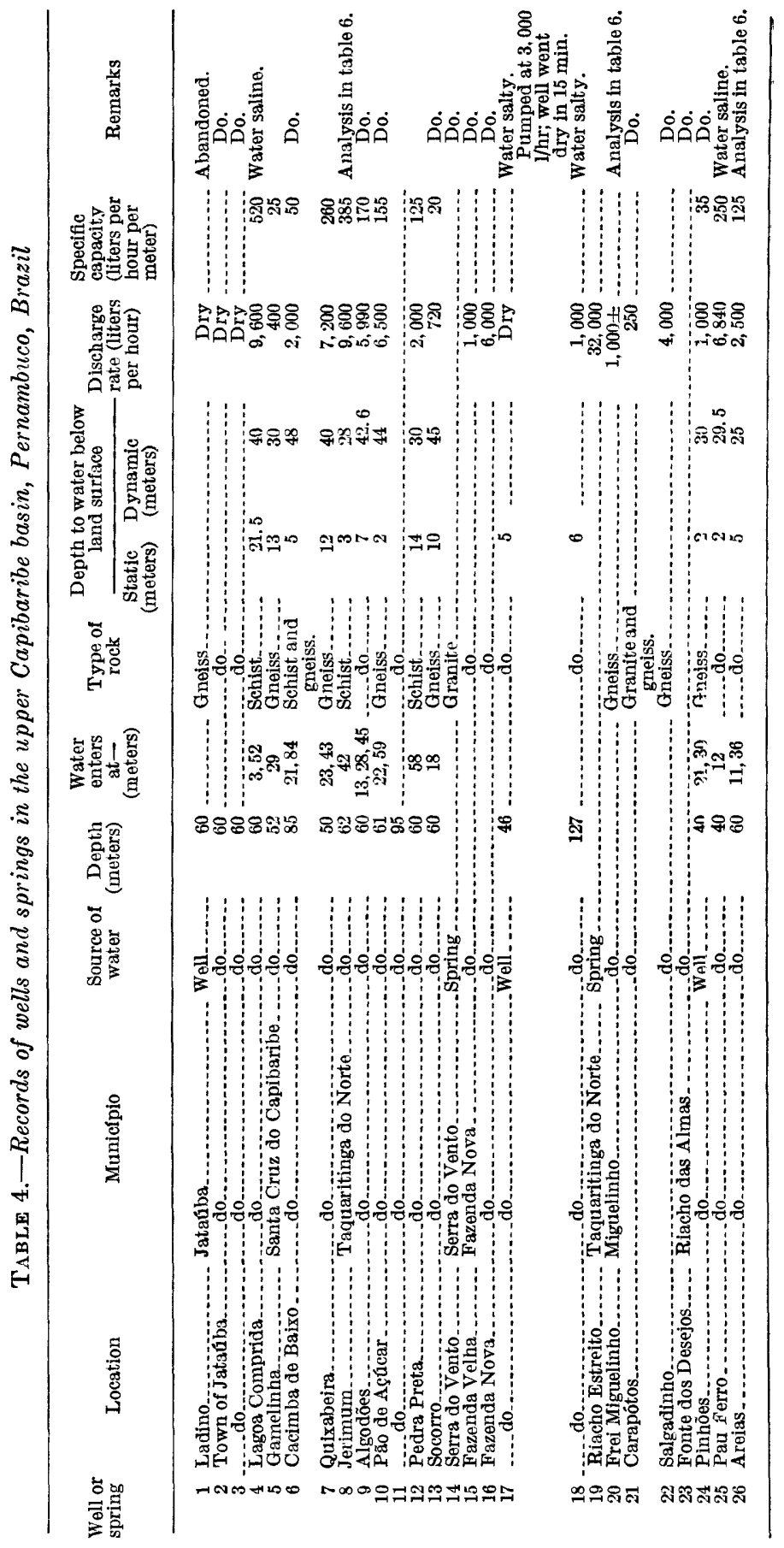


which governs permeability, is irregularly distributed; that is, the rock fails to meet the requirement of homogeneity. This is shown by a pumping test that was made in well 13 at Socorro. The well was pumped $23 \mathrm{hr}$, at an average rate of $750 \mathrm{l} / \mathrm{hr}$. The maximum drawdown could not be determined because measurements of water level could not be made while the pump was in the well. $T$ first measurement after cessation of pumping could only be mado after removal of the pump, a task that required about an hour. Tlus, the large rise of water level that normally occurs promptly after cessation of pumping could not be measured. The rest of the recovery of water level in the well is shown in figure 3. Instead of the straight line that should have been obtained if the conditions of the test rad met all requirements of the nonequilibrium equation, the curve consists of two nearly straight segments. These two segments may show the influence of water-filled fractures at two different depths in the well that contribute water to the well in different amounts. A confficient of transmissibility $(T)$ based on the lower segment is eight times greater than that based on the steeper upper segment. These transmissibilities, therefore, do not describe the transmissibility of an aquifer. They only describe the condition of the rock at the well and are not really coefficients of transmissibility. They tell little or nothing about the condition of the rock even a few meters away from the well, except possibly along the fractures themselves.

\section{SPECIFIC CAPACITY}

The best index to the performance of a well in fractured rocks is its specific capacity, which is the ratio of the discharge, in liters per hour, to the drawdown, in meters, for example, $100 \mathrm{l} / \mathrm{hr} / \mathrm{m}$ (liters per hour per meter). The specific capacities calculated for the wells that were drilled in the upper Capibaribe basin range frcm 0 to $520 \mathrm{l} / \mathrm{hr} / \mathrm{m}$. They are higher for wells in schist $(122 \mathrm{l} / \mathrm{hr} / \mathrm{m})$ than for wells in gneiss $(54 \mathrm{l} / \mathrm{hr} / \mathrm{m})$, but not enough wells were chserved to justify a generalization on the relative performance of wells in these two types of rock. The data tend to agree, however, with other studies on this subject, such as that of Rasmussen (1963, p. 321), who investigated the performance of more than 2,000 wells in fractured rocks of various types and degrees of metamorphism. He fcund the average specific capacity of 481 wells finished in schist to be 25 times as high as the average for 131 wells finished in gneiss.

Geologic inference suggests the same conclusion as that pointed out more than 50 years ago by Sinall $(1914$, p. 117). Schist a rock of relatively low metamorphic rank, has innumerable tiny cleavage planes. These favor rapid weathering and on being opened provide 


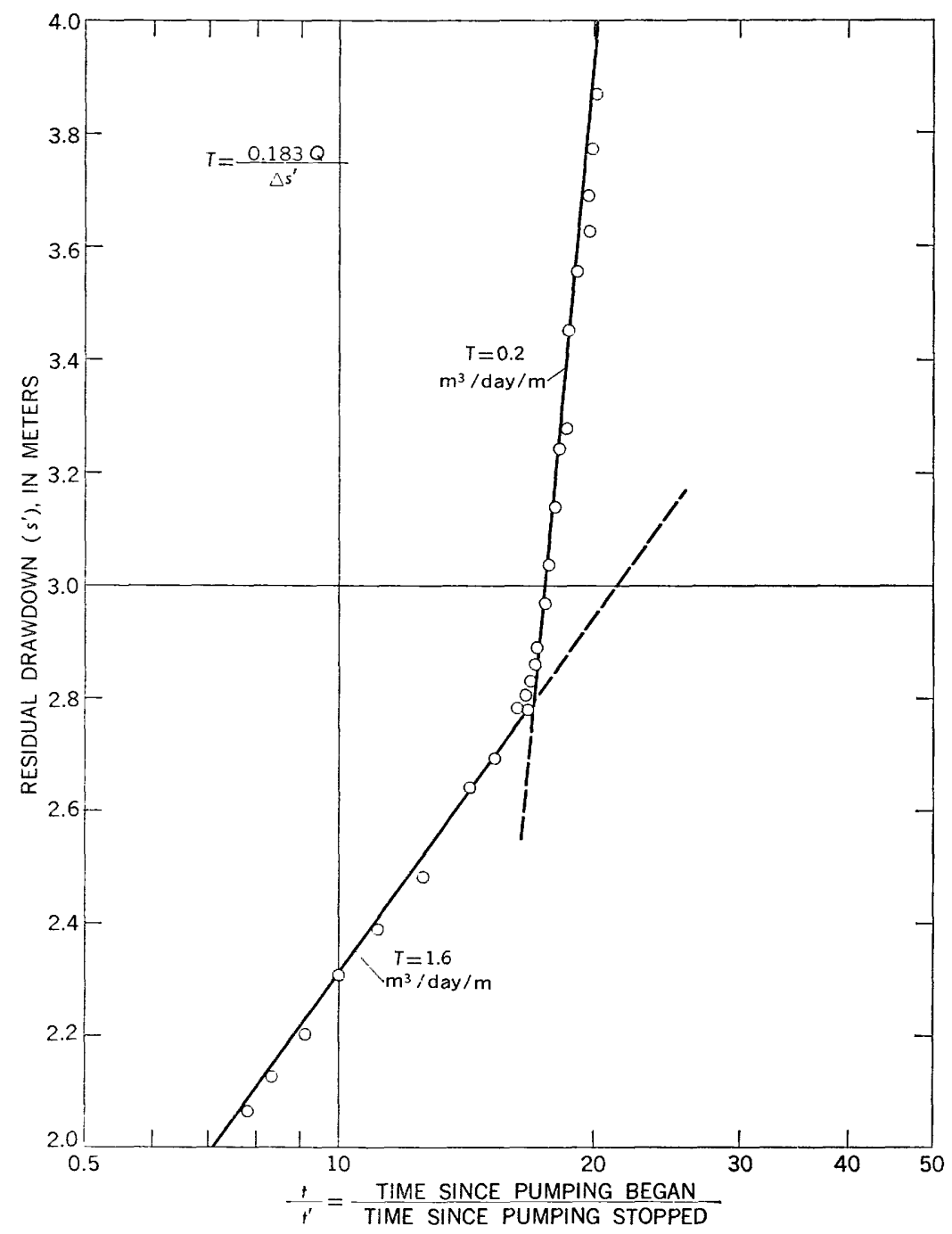

FIGURE 3.-Semilogarithmic curve showing recovery of water level ir well 13.

pore space. On the other hand, the high-ranking metamorphic and the fine-grained igneous rocks are brittle and subject to fracturing, which generally occurs in localized zones rather than throughout the rock. Rasmussen, in the study mentioned above, found that wells in some dense competent rocks, such as rhyolite and kasalt, have high average specific capacities, apparently because the rocks are extensively fractured. 
Where it is continuous and is fairly thick, saprolite makes a reservoir for ground water. The water in it is easily accessiblo, being near the land surface. On the other hand, the saprolite is likely to contain considerable fine-grained material and therefore is not very permeable. Yet, the ground-water potential of saprolite is much greater than that of the parent rock, as Stewart (1962, p. B106-B107) demonstrated in laboratory tests of saprolite from the Georgia Nuclear Laboratory. He found that:

The porosity of the saprolite is greatest-as much as 54 percent-at depths of 30 to 40 feet, but decreases with depth as the saprolite grades into unweathered rock. The porosity of the unweathered rock is about 5 percent, or oneninth the average porosity of the saprolite. The specific yield determined from the same samples decreases with increasing depth, and the amount of water in storage below about 40 feet decreases markedly. The average specific yield of the saprolite is about 21 percent and ranges from about 28 percent in the upper part of the saprolite to 0 in the unweathered rock. *** For all practical purposes, the specific yield of the unweathered rock is zero.

The saprolite in the fairly humid eastern half of the area considered in this report, and in scattered humid areas in the western half, may be thick enough at many places to contain a zone of saturation many meters deep. The possibilities have been suggested by Manoel (1966) in a study of the basin of Riacho Estreito, which is a minor tributary of Riacho do Arroz. Seeking a water supply for the town of Toritama, Manoel found in the Estreito basin springs issuing from saprolite and totaling about $800 \mathrm{cu} \mathrm{m}$ of water per day. $\mathrm{He}$ visualized the saprolite as being fed from fractures in the underlying crystalline basement rock. The water was excellent in quality, having only about 100 to $250 \mathrm{mg} / \mathrm{l}$ (milligrams per liter) in total solids.

The saprolite in most of the western half of the area is likely to be thin, because chemical weathering proceeds slowly under aridity; streamflow is likely to be torrential and carry off the products of rock decomposition nearly as fast as they are produced. Where tre saprolite is too thin to retain water, it is not an aquifer.

\section{WATER IN ALLUVIUM}

The alluvium, where present, is probably the best aquifer available in the upper Capibaribe basin, both as to the quantity and dependability of the water. The fact that several small towns (table 5) rely for water on wells dug into alluvium proves the importance of this source of supply. In addition, many small settlements and farms not listed in the table also depend on water in alluvium. Their number is greater than that of the towns. It is apparent that most of them owe their location to the availability of ground water in the clluvium. 
The alluvium is a useful aquifer only where present ard saturated, and, being a stream deposit, it is restricted to the bottoms of the valleys. In the western part of the basin, the alluvium is thin and discontinuous, but the reaches of the streams having relatively low gradients and slow flow have strips of flood plain under'ain by silty sand accumulated in declining stages of flow. Where thickest, these deposits are several meters deep. At intervals, however, they become thin and disappear, and the bedrock crops out in the channel. At such places, the streams are swift, even making rapids, and they deposit little or no detritus. Thus the alluvial deposits of the western part of the basin form a series of small ground-water reservoirs more or less independent of one another.

TABLE 5.-Cities and towns in the upper Capibaribe basin and their water supplies

[Water not treated]

\begin{tabular}{|c|c|c|c|c|c|}
\hline City or town & $\begin{array}{l}\text { Popula- } \\
\text { tion (1960) }\end{array}$ & $\begin{array}{l}\text { River or other } \\
\text { source }\end{array}$ & $\begin{array}{l}\text { Shallow } \\
\text { well }\end{array}$ & $\begin{array}{l}\text { Small } \\
\text { reservoir }\end{array}$ & $\begin{array}{l}\text { Distribution } \\
\text { system }\end{array}$ \\
\hline Limoeiro................ & 21,252 & Rio Sirigé 1. & & & Yes. \\
\hline Surubim & 6,565 & & & $\bar{x}$ & $\begin{array}{l}\text { Planned or } \\
\text { under construc- } \\
\text { tion. }\end{array}$ \\
\hline $\begin{array}{l}\text { Santa Cruz do Capibaribe. } \\
\text { Tortitama }\end{array}$ & $\begin{array}{l}4,680 \\
3,528\end{array}$ & Rio Capibaribe... & $\mathrm{x}$ & $x$ & $\begin{array}{l}\text { None. } \\
\text { Planned or } \\
\text { under construc } \\
\text { tion. }\end{array}$ \\
\hline $\begin{array}{l}\text { Brejo da Madre de Deus. } \\
\text { Vertentes........ }\end{array}$ & $\begin{array}{l}2,995 \\
2,758\end{array}$ & Stream & & $\begin{array}{l}x \\
X\end{array}$ & $\begin{array}{l}\text { None. } \\
\text { Planned or } \\
\text { under construc- } \\
\text { tion. }\end{array}$ \\
\hline $\begin{array}{l}\text { Taquaritinga do Norte } \\
\text { Fazenda Nova. } \\
\text { Cumaru } \\
\text { Riacho das Almas } \\
\text { Jataúba } \\
\text { Frei Miguelinho } \\
\text { Serra do Vento } \\
\text { Gravatá de Jaburu } \\
\text { Pará } \\
\text { Ameixas } \\
\text { Carapotós. } \\
\text { Poco Fundo }\end{array}$ & $\begin{array}{r}1,777 \\
1,037 \\
955 \\
822 \\
789 \\
625 \\
513 \\
489 \\
288 \\
279 \\
258 \\
194\end{array}$ & $\begin{array}{l}\text { Riacho Taboca } \\
\text { Riacho das Almas. } \\
\text { Riacho do Jatobá. } \\
\text { Stream. } \\
\text { Siacho Pará. }\end{array}$ & $x$ & $\begin{array}{l}x \\
x \\
x\end{array}$ & $\begin{array}{l}\text { Do. } \\
\text { Yes. } \\
\text { None. } \\
\text { None. } \\
\text { None. } \\
\text { None. } \\
\text { None. } \\
\text { None. } \\
\text { None. } \\
\text { None. } \\
\text { None. } \\
\text { None. }\end{array}$ \\
\hline
\end{tabular}

1 Distance, $40 \mathrm{~km}$.

2 Distance, $10 \mathrm{~km}$.

It is essential, of course, that the alluvium be thick enough to extend below the zone of evapotranspiration and below the roots of the phreatophytes, so that a relatively permanent body of ground water can accumulate. This water will move slowly through the lower part of the alluvium, in a zone of greater or lesser thicknass immediately above the surface of the bedrock, until it reaches a place where the alluvium is too thin to contain it. Here it will come to the surface as flow in the river channel or as a spring, or it will be discharged to the atmosphere by evaporation and transpiration. 
Alluvium in the eastern half of the upper Capibaribe basir, where precipitation is heavier than it is farther west and much of the bedrock is schist, is relatively more extensive and may be hydrsulically connected with the mantle of saprolite, which is describer. above. The somewhat greater thickness and volume of alluvium in this part of the basin favor the accumulation of ground water, but the schist on weathering yields more clay than the granite and gneiss fartl or west, so that much relatively impermeable material is included.

\section{CHEMICAL COMPOSITION OF WATER}

All natural waters contain mineral matter in quantities that depend on the type of rock and soil over or through which th? waters have passed, the length of time of contact between the water and earth materials, the amount of carbon dioxide dissolved in the water, the amount of humic acid picked up from the soil, and the provailing conditions of pressure and temperature. In addition, such human activities as the diversion and use of water for irrigation of crops and for other purposes and the disposal of sewage and industrial wastes into streams and wells also alter the composition of water.

The chemical character of the water from wells, springs, and streams in the upper Capibaribe basin is suggested by the analyses presented in table 6 . The well and spring waters were analyzed in the water laboratory of the SUDENE. Most of the chemical constituents ordinarily determined in water intended for human consumption are included in these analyses. The stream waters were tested by field methods, and only the chloride content, hardness, and specific conductance were determined. These determinations prob accurate to within 10 percent. The locations of the samples are shown on plate 1 .

Most of the waters of the upper Capibaribe basin are rather highly mineralized, but there are great differences from one place to another. The residue on evaporation (total dissolved solids) exceeded 1,500 $\mathrm{mg} / \mathrm{l}$ in 11 of the 13 samples analyzed but were below $600 \mathrm{mg} / \mathrm{l}$ in the two others. The maximum residue on evaporation, a leboratory determination, was $13,800 \mathrm{mg} / \mathrm{l}$.

The specific conductance also is a measurement of the total quantity of dissolved mineral matter, although it is not directly comfarable to the residue on evaporation. The specific conductance was lower in the field tests, representing chiefly surface-water sources, than in the laboratory determinations, representing chiefly water from wells in the bedrock and springs. Conductance in the field tests generally ranged from 220 to 5,000 micromhos; in seven of the 15 tests it vas below 1,000 , and in two below 500. Conductance in the laboratory analyses, 
TABLE 6.-Chemical analyses of water from wells, springs,

[Results in milligrams per liter,

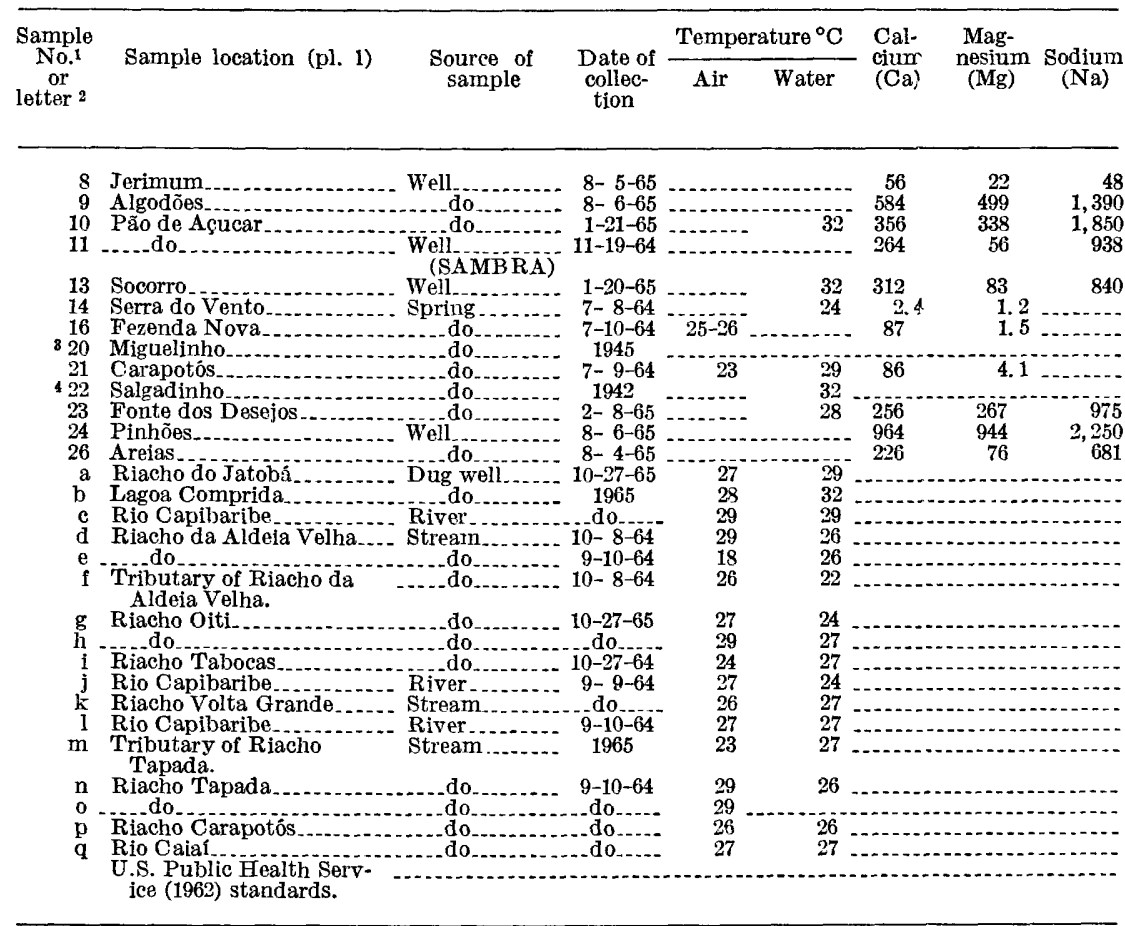

1 Analysis by SUDENE water laboratory.

2 Analysis by field chemical test by the authors.

by contrast, ranged from 750 to 18,800 micromhos and in seven of eight determinations exceeded 4,000. These results suggast that the surface water generally may be less mineralized than the water in the crystalline rocks, or that the surface water had been diluted by recent runoff when the field tests were made.

The concentrations of the various constituents followed much the same pattern as the residue and conductance. The chloride in 27 determinations ranged from 22 to $7,300 \mathrm{mg} / 1$ and was expectably less in the field tests than in the laboratory analyses. It was below $1,000 \mathrm{mg} / \mathrm{l}$ in only four of the well and spring waters but was below this amount in seven of 13 surface waters. Sodium, which combines principally with chloride to form ordinary salt, also is abundant in the water, generally ranging in 11 samples from 20 to $2,250 \mathrm{mg} / \mathrm{l}$. Sulfate ranged in 12 laboratory analyses from 5.3 to $615 \mathrm{mg} / \mathrm{l}$, exceeding 300 in seven of them. 
and streams in the upper Capibaribe basin, Pernambuco

except as indicated. Tr., trace]

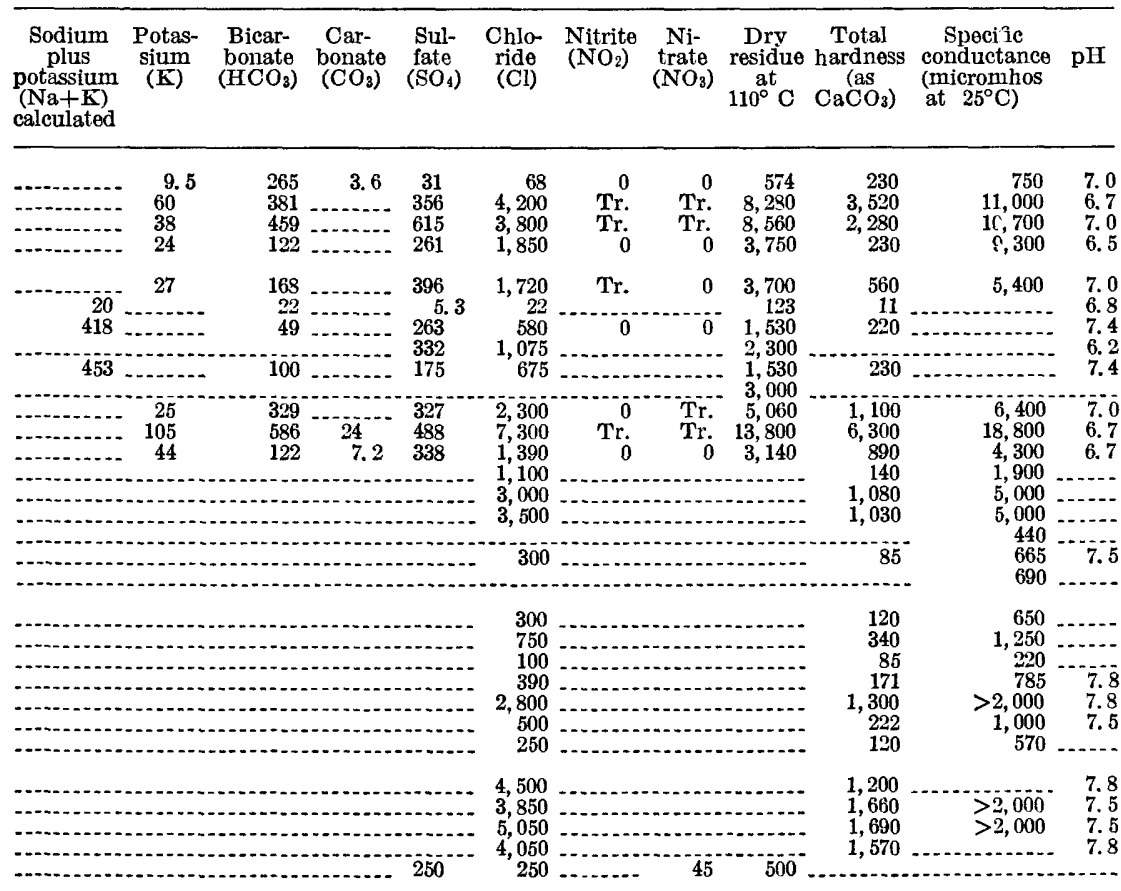

3 Teixeira (1945. sample 5291).

4 Pinto (1942, average of five springs).

Most of the waters of the upper Capibaribe basin can be classified as sodium chloride water because, although sodium was not determined in the field tests, the large amounts of chloride shown by some of these tests imply corresponding amounts of sodium. The salinity of water from streams increases downstream, at least in some cases. Riacho Oiti, for example, was tested near Brejo da Madre de Deus and also where it enters Riacho da Aldeia Velha, about $10 \mathrm{~km}$ downstream. The streamflow diminished by about one-half through this stretch of the stream, and the chloride, hardness, and specific conductance approximately doubled. The two tests were made within an hour of each other.

\section{SUITABILITY OF WATER FOR HUMAN CONSUMPTION}

Standards by which to judge the potability of water differ from one country to another, often seeming to be governed more by the chemical quality of the water actually available than by the possible 
effect of the water on the inhabitants. Where water having a low mineral content is not available, water having more mineral matter will perforce be used. The limits of mineral concentration set or suggested by public agencies are likely to be a compromise between the water quality desired and the water quality available in quantities sufficient to meet the demand and are likely to be an ideal objective to be sought, not a boundary where thirst begins. The limits of concentration suggested by the U.S. Public Health Service (1962) relative to sulfate, chloride, nitrate, and total dissolved solids are given in table 6 . The standards proposed by Schoeller (1962) relative to totsl solids have been quoted in some Brazilian reports (Costa, 1963, p. 14) and are as follows:

$\begin{array}{lr}\begin{array}{l}\text { Potability } \\ \text { Good }\end{array} & \text { Dry residue }(\mathrm{mg} / \mathrm{l}) \\ \text { Acceptable } & \text { Ur to } 500 \\ \text { Poor }-1000 & 500-1,000 \\ \text { Bad }-1,000-2,000 \\ \end{array}$

By these standards, several of the waters from the upper Capibaribe basin can only be classified as "bad."

\section{SUITABILITY OF WATER FOR CATTLE}

Cattle can drink water that is considerably more minaralized than humans can tolerate. Citing Bateman, Costa (1963, p. 14) gives the Iollowing classification of water for use by animals:

\begin{tabular}{|c|c|}
\hline & ry residue $(\mathrm{mg} / \mathrm{l})$ \\
\hline Horses drink readily & $5,000-6,250$ \\
\hline Horses & $6,250-7,800$ \\
\hline Catt & $7,800-9,375$ \\
\hline & $9,375-15,605$ \\
\hline eyond limit & 15,605 \\
\hline
\end{tabular}

By these standards, most of the waters sampled in the upper Capibaribe basin would be acceptable for at least limited use by animals, and some would be entirely acceptable.

\section{SUITABILITY OF WATER FOR IRRIGATIOJT}

Several factors in addition to mineral content determine whether water is suitable for irrigation use. Among them are the amount of water applied to the soil, the amount and distribution of rain, and the drainage and physical and chemical character of the soil. If the concentration is not excessive, some dissolved salts favor plant growth, but others are harmful to plants or to soils. The total conc?ntrations of dissolved salts in water range from a few to many thousand $\mathrm{mg} / \mathrm{l}$, but in most irrigation waters are in the range of 100 to $1,500 \mathrm{mg} / \mathrm{l}$. 
The U.S. Salinity Laboratory Staff (195t, p. 69-81) states that the most important characteristics of water for irrigation are: (1) total concentration of soluble salts, (2) relative proportion of sodium to other cations, (3) concentration of boron or other elements that may be toxic, and under some conditions (4) the bicarbonate concentration as related to the concentration of calcium plus magnesium.

The Salinity Laboratory devised a system for classifying waters with respect to their suitability for use in irrigation, based on the specific conductance of the water and a calculated value called the sodium-adsorption-ratio (SAR). Details of this system of classification will be found in the report by the Laboratory. The waters of the upper Capibaribe basin are either so mineralized that they would be satisfactory only for limited use on well-drained soils and with plants having a high tolerance for salinity, or they are so limited in quantity that even small-scale irrigation is hardly practical.

\section{PRESENT DEVELOPMENT OF WATER RESOURCES}

Residents of the upper Capibaribe basin meet their needs for water by using either surface water or ground water, depending on which is available locally. Much of the water used by cattle, by many rural residents, and also by those living in towns and villages is taken from small artificial ponds or from shallow open excavations adjacert to the streams and even in the stream bed itself. The excavations are often destroyed in floods. Rarely are they or the ponds protected against contamination. Use of water from the ponds and excavations for human consumption is a hazard to health, but it continues because the construction cost of the ponds and shallow excavations is small, even negligible, and because other means of developing water mry seem nonexistent. The water of the ponds is considered to be surface water because it is on the land surface. The water of the shallow pits is considered to be ground water because it is found below the land surface and is not flowing perceptibly, but in many situations it has infiltrated into the bed of an adjacent stream and has essentially the same chemical characteristics as the stream.

Most of the towns rely on water stored in small reservoirs, although a few use water from the open pits. Limoeiro brings water from a river $40 \mathrm{~km}$ distant, and Fazenda Nova brings it $10 \mathrm{~km}$. No town in the basin treats the water. None uses a well more than a few meters deep. The available information on these and other public supplies is given in table 5 .

The cottonseed cake plant at Socorro uses a well $60 \mathrm{~m}$ deep to provide its water supply, but most other commercial and industrial establishments depend on water from small reservoirs or from shallow excavations. 


\section{FUTURE DEVELOPMENT OF WATER RESOURCES}

The future development of water resources in the uppor Capibaribe basin is likely to follow the types of development that have already been undertaken. The construction of a large reservoir for impounding water for irrigation does not seem likely for various reasc $n$ s previously mentioned. Moreover, the development of extensive well irrigation is not likely because - to mention only one reason-no aquifer capable of supplying water in sufficient quantity seems to exist in the basin. However, small dams for impounding small quantities of water probably will be constructed in increasing numbers, and these will supply water for home use, for cattle, and for towns, as in the past. Wells, also, will become more numerous, and more attention than in the past will be given to locating them in accord with geologic criteria, but at best some will be unsuccessful. The wells will supply water for the s?me purposes as the small reservoirs. The future development, hence, will probably use the water that is available in the basin more fully than before.

Some of the methods that may be employed in this intensified development are suggested below. Shallow wells driven or dug into the alluvium offer a practical inexpensive means of providing water for cattle at many places. The quantity of water taken fron such wells generally is small and is not likely to create local shorteges of water by overdraft.

Wells in the saprolite, where it is thick enough to contain a zone of saturation, could also supply water for homes and cattle and could be especially valuable at localities remote from streams. The identification of favorable well sites in the saprolite is more difficult than for wells drilled into alluvium, and more wells may be unsiccessful for this reason. Dug wells are likely to be more satisfactory than either drilled or driven wells, because the permeability of saprclite is generally low. A well exposing a relatively large area of aquifer in its walls will collect considerable water even though the infiltration rate is low. It will also store a quantity of water that is immediately available for withdrawal at a rate greater than the infiltration rate.

Greater use probably could be made of rain water than at present. Cisterns, for example, can be used for storing large quantities of water collected from the roofs of houses or from land surfaces. Cederstrom and Assad (1964, p. 24-28, 36-39) describe and illustrate cisterns. They alsa suggest how fracture systems in crystalline rocks might be recharged by injecting surface water into them through wells penetrating the rocks. Such recharge could overcome, to some derree, the objectionable mineral content of the ground water. They say, "The quality of the water will be improved by dilution; stronger hydraulic gradients will be established which will promote circulation and further improvement in quality." 


\section{SUMMARY AND CONCLUSIONS}

The upper Capibaribe basin has water, both on the land surface and underground, that can be developed more fully than at present, but the task of developing it is far from simple. Haphazard methods will produce only accidental successes, and even carefully planned, scientifically controlled methods will occasionally fail.

The upper Capibaribe basin has, at best, ony a small supply of water, and this small supply is unevenly distributed. This is true wh ther we think of surface water, ground water, or precipitation. Furthermore much of the water that is available in the basin is of inferior chemical quality. An adequate supply of good water is, therefore, an irvaluable asset. Lack of such a supply may retard or prevent the ecor omic development of a locality, or mean inevitable failure for an enterprise. The search for water in the basin will be attended by a higher percentage of failures than in regions more abundantly provided with water simply because the opportunities for failure are more numerous.

The foregoing is true because the bedrock in the basin is hard, dense crystalline rock having little or no primary porosity and having its secondary porosity confined to certain places, generally elongated zones of fracturing. Large areas between fracture zones are essentially solid rock having only negligible primary porosity, and wells here are doomed to failure.

Fortunately, many of the valleys have formed along fractures which have facilitated erosion because they are weak places in the rock. The valleys are also the places where runoff collects. This runoff is available to fill the fractures, which therefore are better supplied with water than they would be if in the highlands between streams. Wells afford a practical means of developing supplies of water from the bedrock, but the big problem is where to locate them. They will have the best chance to be successful if they intersect a fracture or fracture system that can be supplied with water from the land surface. This means, in general, that sites in the lower parts of the valleys should be best, but even where sites are selected on the basis of geologic criteria, some wells will fail because the fractures where intersected by the wells vill prove to be sealed.

Saprolite is widespread in the basin but is irregular in thickness, being absent at many places. Its porosity is likely to be low rather than high, and much of it, especially in the western part of the basin, is above the water table. Wells in the saprolite will be successful where the saprolite extends below the water table but generally will yield only relatively small quantities of water because the saprolite is likely to be clayey. 
The alluvium is the best aquifer in the basin but is restricted to the valley bottoms and is interrupted along the valleys where rock comes to the surface. It consists of a series of small reservoirs rather than one continuous reservoir. The water in the alluvium is near the land surface, and no well in the alluvium can be deep because the alluvium at no place is more than about $5 \mathrm{~m}$ thick. Wells can be dug by hand in the alluvium, or well points can be driven into it with simple tools. Wells will be most productive and dependable if located where the alluvium is widest and is continuous for several kilome+ers. Where the chemical quality of the water is important, as where potable water is desired, a tributary emptying into the main stream mey be a site where, through dilution, the chemical quality of the water is better than average.

The fact that both the fractured bedrock and the alluvium are concentrated along the valleys means that large areas between streams have only the saprolite and minor fractures in the bedrock as possible sources of water. Lacking water in them, these areas are denendent on precipitation or on water brought in by truck or pipeline.

The mineral content of the water in the basin severely limits the usefulness of the water. At a few places the water is entirely satisfactory for human consumption. These are likely to be places where the supply is frequently replenished from precipitation and the circulation of water is fairly active, or even vigorous. But at many places the water is satisfactory only for consumption by animals, and at some places it is not good even for them. Irrigation with ground water generally is not practicable because of the high mineral content of the water, even where the quantity of water is sufficient. The quality of the ground water may be improved in some situations by pumping water from wells to give fresh water a chance to enter the rocks. Diluting pumped ground water with stored rain water may also be a means of obtaining a supply of potable water.

The sanitary condition of the water generally used in the area is dubious. Measures to control contamination or to purify the water are virtually unknown. The construction of infiltration galleries, screened wells, or dug wells walled with rock or cement which replace the water holes now commonly used would do much to improve the sanitary condition of the water and concurrently the health of the local population.

Not all the water problems of the upper Capibaribe basin can be solved by drilling water wells. Some problems can best be solved by building dams to impound water and should be solved in this way in order to use fully the water that is arailable. The selection of dam sites was not an objective of this investigation, but small dams probably could be built and perhaps would be practical at many places. Considerations at each possible dam site include, besides topography and 
foundation rock, the quantity of water available to fill the reservoir, the usefulness of impounded water at that place, and the prok able rate of water circulation through the reservoir. The last item is important because without circulation, or at least without occasional flushing of the reservoir, the stored water will progressively become saline, owing to evaporation.

\section{SELECTED REFERENCES}

Branner, J. C., 1902, Geology of the northeast coast of Brazil : Geol. Soc. America Bull., v. 13, p. 41-98.

Cederstrom, D. J., and Assad, J. C., 1964, Observações hidrológicas ro nordeste do Brasil : Div. Geologia e Mineralogia Notas Prelim. e Estudos J.20, 42 p.

Corbett, D. M., and others, 1943, Stream-gaging procedure, a manual describing methods and practices of the Geological Survey: U.S. Geol. Sur"ey WaterSupply Paper 888, 245 p.

Costa, W. D., 1963, Roteiro de excursão, hidrogeologia no cristalino, Região Monteiro-Sumé, Pb.: 17 ${ }^{\circ}$ Cong. Nac. de Geol., Rio de Janeiro 1963, 22 p.

Crandall, Roderic, 1910, Geografia, geologia, supprimento d'água, transporte, e açudagem : Inspectoria das Obras Contra as Sêcas, Pub. 10, sar. IB., D., $131 \mathrm{p}$.

Crandall, Roderic, and Williams, H. E., 1910, Mapa do estado de Ceará, escala 1:650,000: Inspectoria das Obras Contra as Sêcas, Pub. 6, ser. I.G.

Departamento Nacional de Obras Contra as Sêcas, 1958, Mapa de isoiotas anuais do Atlas pluviometrico do Nordeste do Brasil, 1912-1958: Dept. Nac. Obras Contra Sêcas, $1: 2,500,000$.

Departamento Nacional de Produção Mineral, 1918, Atlas pluvionetrico do Brasil, 1914-38: Dept. Nac. Produçāo Mineral, Bol. 5, 48 p., 25 maps.

Dias, J. D. O., 1957, Mapa geológico do Estado de Pernambuco: Uniт. Rural de Pernambuco, Monografias 2.

Ebert, Heinz, 1955, Pesquisas na parte suleste do Estado de Minas Gerais; II, Pesquisas no Polígona das Sêcas: Div. Geologia e Mineralogia, Relatório. Anual do Director, 1954, p. 85-88.

1962, Baustil und regional metamorphose im prakambrischen Grundgebirge Brasiliens : Tshermaks Mineralogische u. Petrographische Mitteilungen, v. 8, no. 1. (In Portuguese, Tectónica e metamorfismo regional do escudo brasileiro, trans. by Gerard Beurlen: Superintendência do Deservolvimento do Nordeste, 38 p.)

Guimarães, Djalma, 1958, Geologia estratigráfica e econômica do Brasil : Estabelecimento, Gráficos, Belo Horizonte.

Horton, R. E., 1916, Some better Kutter's coefficients: Eng. News, v. 75, p. 373, 863.

Johnston, W. D., Jr., and Vasconcelos, F. M., 1944, Tungstênio na. Paraiba e Rio Grande do Norte: Brasil Div. Fomento Produção Mineral Avulso 52, 37 p. ; 1943, Ministerio da Metalurgia, v. 7, no. 41, p. 247-60.

Mangualde, D. L. de, 1945, Geologia da provincia tântalo-glucinífera da Borborema : Brazil Div. Fomento Produção Mineral Bol. 73, p. 3£-72.

Manoel Filho, João, 1966, Estudo hidrogeológico da região de Møteus Viera, Municipio de Taquaritinga do Norte, Pe: Superintendência do Desenvolvimento do Nordeste, 9 p., 3 figs. 
Morães, L. J. de, 1928, Estudos geológicos no estado de Pernaml rco: Serviço Geol. Min., Bol. 32, 100 p., 1 map.

Oliveira, A. J. de, and Leonardos, O. H., 1943, Geologia do Brasil [2d ed.]: Ministerio da Agricultura, Serie Didática, no. 2. 813 o.

Oliveira, E. P. de, 1923, Nota preliminar sôbre as jazidas de cołre de Pedra Branca, estados de Parahyba e Rio Grande do Norte: Ministério Agricultura Industrial Commercial Bol., ano 12, no. 3, p. 75-114.

Pinto, M. da S., 1942a, Nota previa sôbre os serviços de captacão das fontes de Salgadinho: Pernambuco Secretaria Agricultura e Industria Commercial, Bol, v. 9, no. 2, p. 95-100, map.

-1942b, Nota sôbre as fontes de Fazenda Nova, Fazenda Velha e Carapotos : Pernambuco Secretaria Agricultura e Industria Commercial, Bol. 1. 9, no. 2, p. 101-103.

Rasmussen, W. C., 1963, Permeability and storage of heterogeneous aquifiers in the United States: I.A.S.H. Pub. 64, Comm. of Subterranean Waters, p. 317325.

Rolff, P. A. M. de A., 1945a Geologia da provincia tãntalo-glucinífero da Borborema: Div. Fomento Produça Mineral Bol. 73, p. 33-72.

$1945 \mathrm{~b}$, Notas sóbre a geologia do Nordeste: Ministério da Metalurgia, v. 8, no. 47, p. 321-323.

Small, H. L., 1914, Geologia e suprimento d'água subterrânea no Piauhy e parte do Ceará [2d ed] : Inspectoria das Obras Contra as Sêcas, ser. I., D., no. 32, $137 \mathrm{p}$.

Stewart, J. W., 1962, Water-yielding potential of weathered crystalline rocks at the Georgia Nuclear Laboratory: U.S. Geol. Survey Prof. Faper 450-B, p. B106-B107.

Teixeira, A. da S., 1945, Águas minerais de Frei Miguelinho: Pernembuco Secr. Agr. Ind. Com., Bol. v. 12, no. 1, p. 58-61.

U.S. Public Health Service, 1962, Drinking water standards, 1962: Pub. 956, 61 p.

U.S. Salinity Laboratory Staff, 1954, Diagnosis and improvements $0^{f}$ saline and alkali soils : U.S. Dept. Agriculture Handb. 60,160 p.

Williams, H. E., 1926, Notas sôbre a geologia e os recursos minerais do norte do Ceará : Brasil Serviço Geol. Mineral Bol. 16, 42 p. 


\section{INDEX}

\section{[Italic page number indicates major reference]}

\begin{tabular}{|c|c|}
\hline Page & Page \\
\hline cknowledgments... & ivestigation, \\
\hline lluvium & \\
\hline$\ldots 32,40$ & \\
\hline 31 & Irrigation... \\
\hline (n) & \\
\hline polinário $\ldots \ldots \ldots$ & $7,11,15,17$, \\
\hline quifer, alluvium $\ldots \ldots \ldots \ldots \ldots \ldots$ & \\
\hline 27 & rea... \\
\hline 9,11 & \\
\hline de Deus...2, $7,8,9,10,11,15,17,35$ & (n) \\
\hline 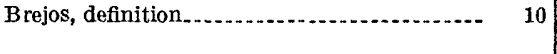 & s \\
\hline 9 & (n) \\
\hline (n) & (n......... \\
\hline ande. & \\
\hline (2) & (n........ \\
\hline 4,11 & (n) \\
\hline (n) & Estado de_.................................... \\
\hline $9,10,11$ & - \\
\hline 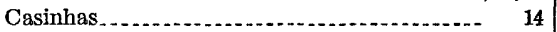 & 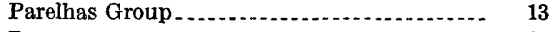 \\
\hline $\mathrm{o} \mathrm{de}$ & - \\
\hline (1) & $\cdots$ \\
\hline - & (n) \\
\hline osition of water & (2) \\
\hline (2) & (2) \\
\hline (n) & rborema \\
\hline ovince, sedimentary............. & $8,15,17,24$ \\
\hline cks, definition & 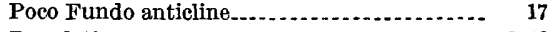 \\
\hline 9,14 & (n) \\
\hline (a. & ian rocks. \\
\hline (- & - \\
\hline $4,7,8$ & Irilling operations \\
\hline 2,11 & non \\
\hline n & 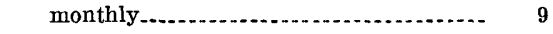 \\
\hline (n) & \\
\hline 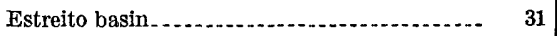 & Quixaba For \\
\hline 24,26 & \\
\hline tial....... & \\
\hline $7,11,15,17,37$ & $\begin{array}{l}\text { Recife } \\
\text { Reservoirs, ground-water } \ldots . . .4,4,10,11\end{array}$ \\
\hline (1) & - \\
\hline (n) & eia Velha \\
\hline n....... & $\begin{array}{l}\text { lmas. } \\
\text { gnas_. }\end{array}$ \\
\hline$\cdots$ & 31 \\
\hline 11 & $\mathbf{H}$ \\
\hline 1 & 31 \\
\hline 16 & Velha................... \\
\hline $2,23,25$ & (2n-1) \\
\hline 18 & (-2-1, \\
\hline 33 & 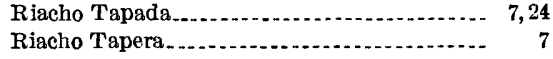 \\
\hline 22 & Tolta Grande...- \\
\hline 年 & 5 \\
\hline 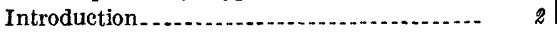 & \\
\hline
\end{tabular}




\begin{tabular}{|c|c|}
\hline & \\
\hline algadinho ............ E4,7 & Temperature, averages........ \\
\hline anta Cruz... 17 & Topography \\
\hline unta Cruz do Capibaribe.................. 2, 7,18 & Toritama \\
\hline ăo Caitano & Transportation........ \\
\hline prolite $\ldots \ldots$ & \\
\hline 31 & Várzea Escondida...... \\
\hline Formal & Vertentes.... \\
\hline rra da Taquara & \\
\hline Vento & Water, alluvium \\
\hline 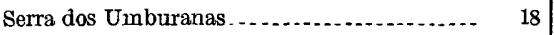 & (n) \\
\hline corro & future development.......................... \\
\hline $\begin{array}{l}\text { Specific conductance, surface- and ground- } \\
\text { water }\end{array}$ & 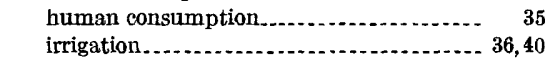 \\
\hline (n).... & Precambrian rocks... \\
\hline $\mathrm{w}_{-} .$. & \\
\hline nd conclusions.......................... & mination cortrol... \\
\hline (n) & (n) \\
\hline cific conductance.......................... & Weath \\
\hline Surubim $\ldots \ldots \ldots \ldots \ldots$ & Wells $\quad$ discharge \\
\hline 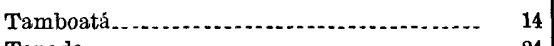 & 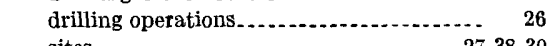 \\
\hline 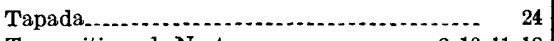 & 27 \\
\hline itinga do Norte_................. 2, & \\
\hline
\end{tabular}



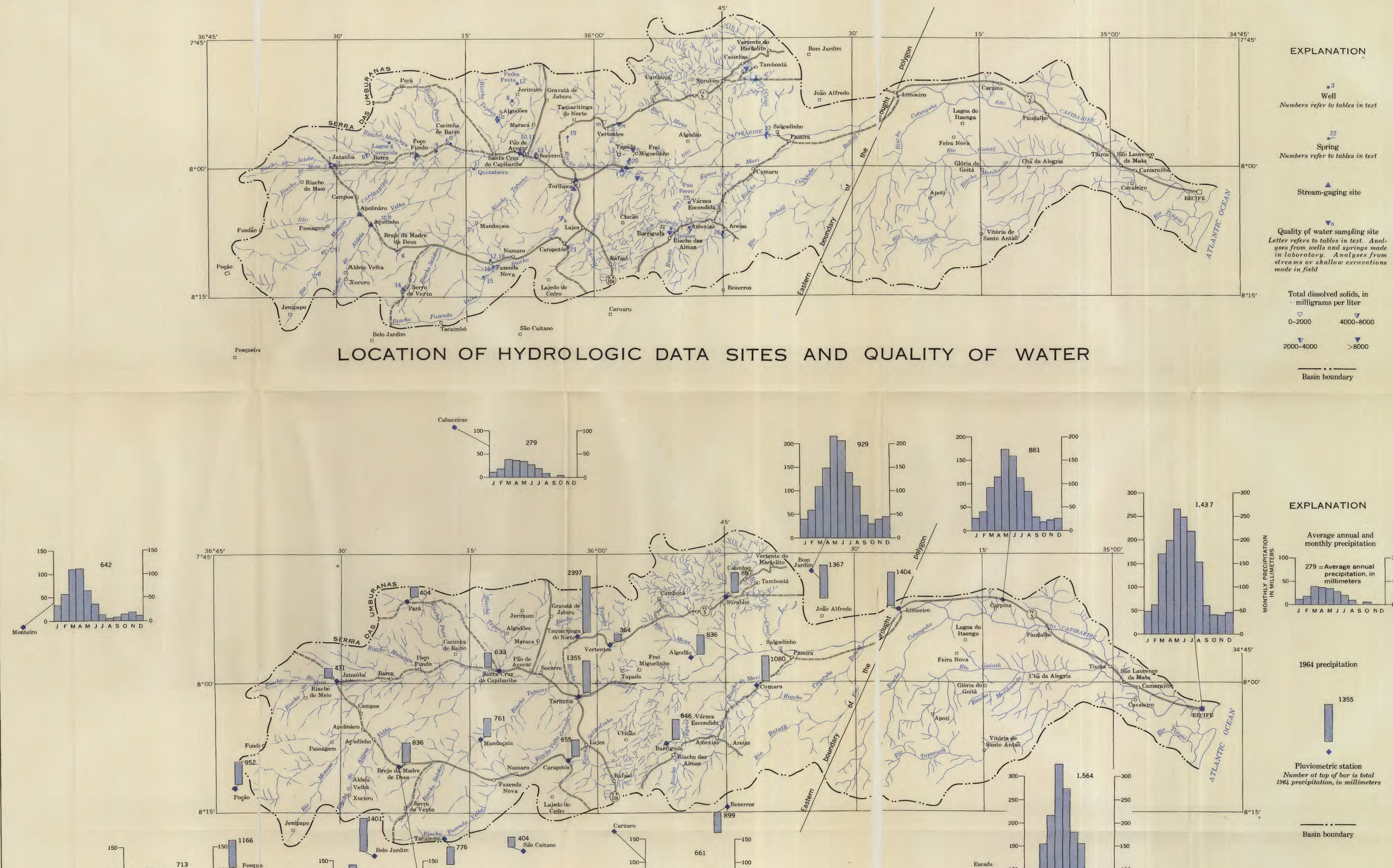

EXPLANATION

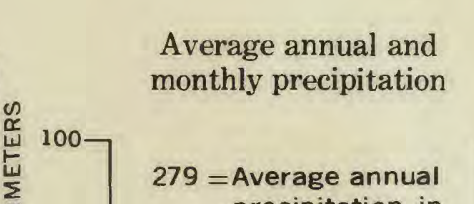

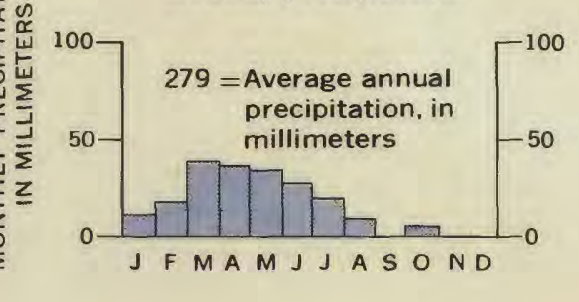
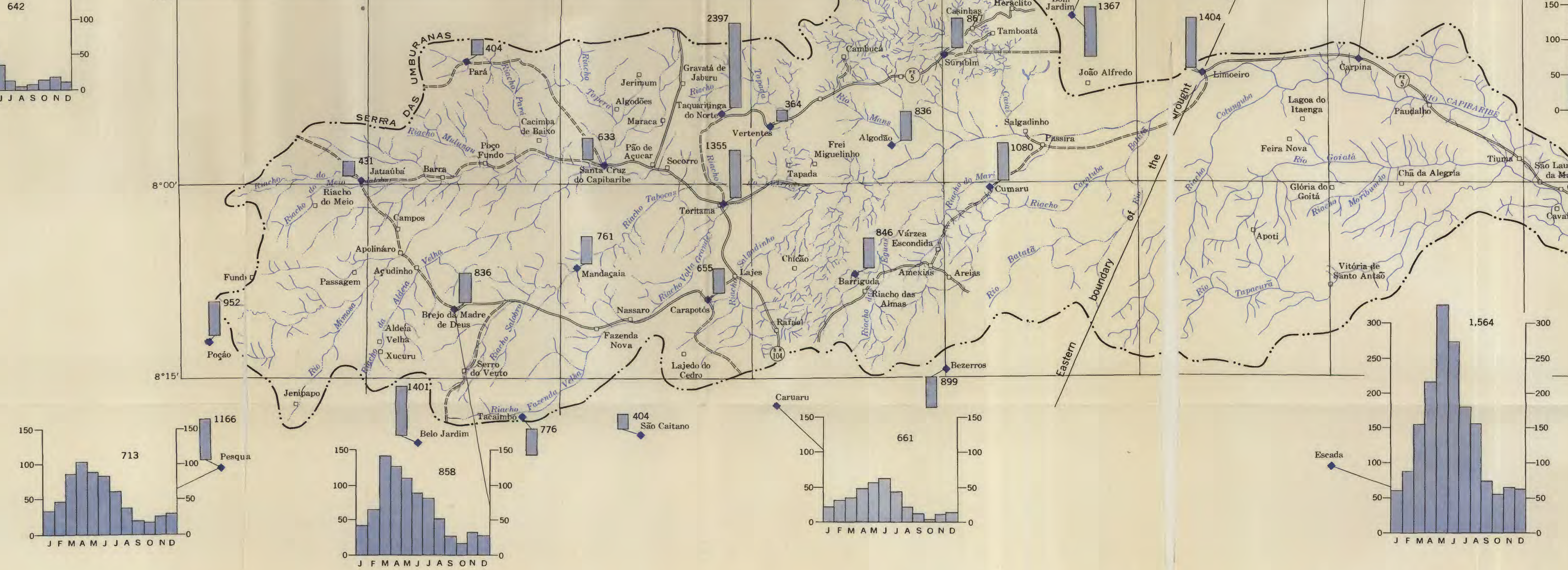

PRECIPITATION AT PLUVIOMETRIC STATIONS WITHIN AND NEAR THE BASIN

EPLANATION

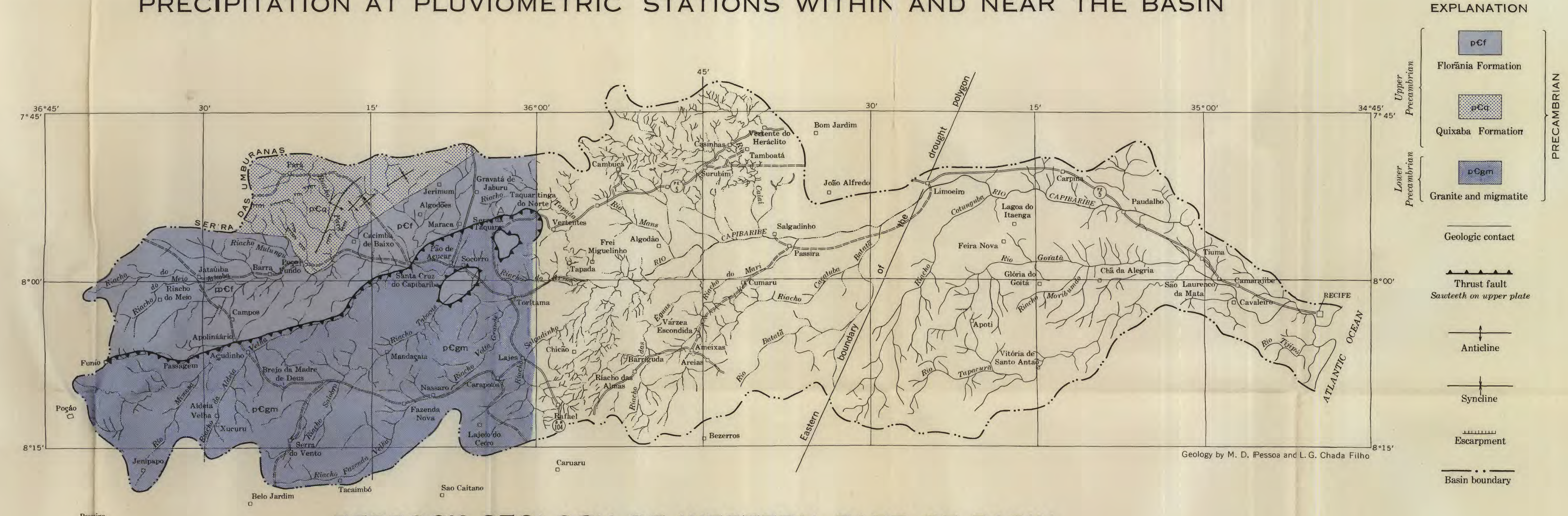

BEDROCK GEOLOGY OF WESTERN PART OF BASIN

HYDROGEOLOGIC MAPS OF THE CAPIBARIBE BAS] N, PERNAMBUCO, BRAZIL

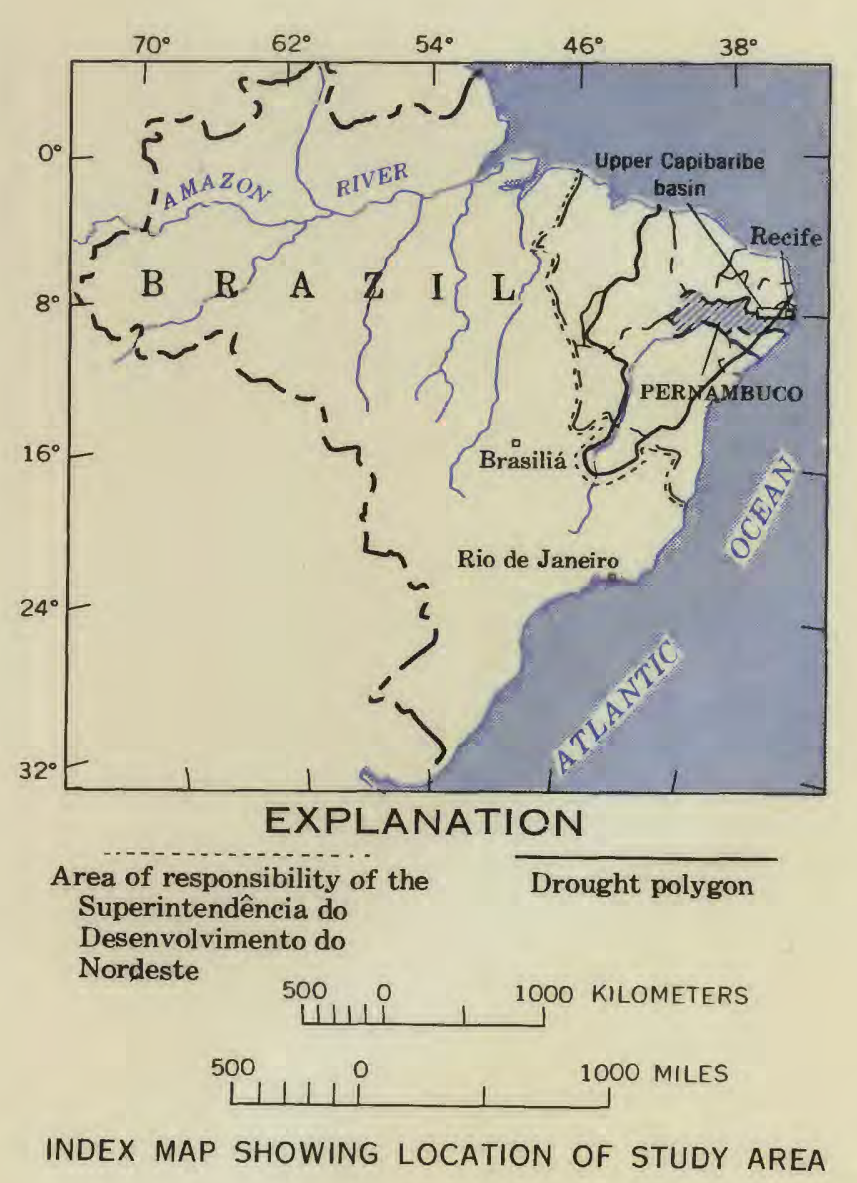

